\title{
Ancient Maya use of Hidden Soilscapes in the Yalahau Wetlands, northern Quintana Roo, Mexico
}

\author{
Daniel Leonard, Sergey Sedov, Elizabeth Solleiro-Rebolledo, Scott L. Fedick, Jaime Diaz
}

Daniel Leonard

dleon004@ucredu

HDR, Inc., San Diego, 92123, California, U.S.A.

\section{Sergey Sedov}

Elizabeth Solleiro-Rebolledo

Jaime Diaz

Instituto de Geología, Universidad Nacional Autónoma de México, Ciudad Universitaria, Coyoacán 04510, CDMX, Mexico.

\section{Scott L. Fedick}

Department of Anthropology, University of California Riverside, Riverside, 92521 California, U.S.A.

Department of Anthropology, Rhode Island College, Providence, 02908 Rhode Island, U.S.A.

BOL. SOC. GEOL. MEX. 2019

VOL. 71 NO. 1

P. $93-119$

http://dx.doi.org/10.18268/BSGM2019v7 lnla6

Manuscript received: April 28, 2017

Corrected manuscript received: December 31, 2017.

Manuscript accepted: February 12, 2018.

\section{ABSTRACT}

The Yalahau region of northern Quintana Roo, Mexico, contains abundant freshwater wetland and a history of Maya occupation that spans nearly 3000 years. The highest regional population levels occurred during the Late Preclassic period, from $c a$. $100 \mathrm{BC}$ to $\mathrm{AD} 350 / 450$. The Maya constructed rock alignments crossing wetland swales, and these have been hypothesized as features used to trap soil and water for production of food and useful biological resources such as periphyton. Paleoenvironmental studies from a wetland in the eastern part of the region suggested that occupation of the Yalahau region, and manipulation of the wetlands, corresponded to a period when the water table was lower than in modern times, creating wetland ecosystems that were most productive for cultivation. This paper presents results that apply this model at the regional scale (in wetlands in other parts of the region). Thirty short soil cores were collected from 12 wetlands across the region. For this project, 5 cores from 4 wetlands were selected for analyses including micromorphology and radiocarbon dating. Thin sections studied under petrographic microscope were used to identify the various types of features present in the core sequences including carbonates, organic matter, shell, pyrite, gypsum, and pore space. In each core, it was possible to distinguish an upper unit dominated by biogenic-micritic carbonate and a lower unit characterized by a variety of unique soil features such as sparitic calcite crystals, pyrite, gypsum, and gleyic properties. Based on this, it is suggested that while modern soil forming processes are fairly uniform across the region and controlled by regular annual flooding ( $\sim 7$ months of $>1 \mathrm{~m}$ deep flooding each year), in the past (Preclassic period), flooding was less regular and wetland environments were more swampy and varied. Furthermore, it is suggested that the Preclassic depressions encountered by the Maya were a prime agricultural resource that allowed the region to flourish during the Late Preclassic period. However, as flooding became more regular at the end of the Preclassic period, the region was abandoned, only to be reoccupied in the Late Postclassic when wetlands were exploited for aquatic resources rather than for agriculture.

Keywords: Maya, wetland agriculture, micromorphology, paleoenvironmental change, pedogenesis, geoarchaeology.

\section{RESUMEN}

La región de Yalahau al norte de Ouintana Roo, México, contiene abundantes humedales de agua dulce y una historia de ocupación Maya que abarca casi 3000 años. Los mayores niveles de población regional ocurrieron durante el periodo Preclásico tardío, del $100 \mathrm{AC}$ al 350/450 DC. Los Mayas construyeron alineamientos rocosos cruzando los pantanos, y se ha hipotetizado que estas características funcionaron para atrapar suelos y agua para la producción de alimento y para el uso de recursos biológicos como el perifiton. Los estudios paleoambientales de un humedal de la porción oriental de la región sugieren que la ocupación de la región de Yalahau y la manipulación de los humedales, corresponden con un periodo cuando el manto freático fue menor que en tiempos modernos, creando ecosistemas de humedal que eran más productivos para el cultivo. Este trabajo presenta resultados que aplican este modelo a escala regional (en humedales en otras partes de la región). Treinta pequeños núcleos de suelo fueron colectados de 12 humedales a lo largo de la región. Para este Proyecto, 5 núcleos de 4 humedales fueron seleccionados para los análisis que incluyen micromorfología y fechamiento por radiocarbono. Las láminas delgadas, estudiadas bajo el microscopio petrográfico, fueron usadas para identificar los varios tipos de características presentes en los núcleos, incluyendo carbonatos, materia orgánica, conchas, pirita, yeso y espacio poroso. En cada núcleo, distinguimos una unidad superior dominada por carbonato micrítico biogénico y una unidad inferior caracterizada por una variedad de características de suelo únicas, como cristales esparíticos de calcita, pirita, yeso y propiedades gléycas. Basado en esto, se sugiere que mientras que los procesos formadores del suelo moderno son claramente uniformes a lo largo de la región y controlados por la inundación anual regular ( $\sim 7$ meses de $>1 \mathrm{~m}$ de profundidad de inundación cada año), en el pasado (periodo Preclásico), la inundación era menos regular y los ambientes de humedal fueron más pantanosos y variados. Además, se sugiere que las depresiones del Preclásico encontradas por los Mayas, fueron un recurso agrícola de calidad que permitió el florecimiento de la región durante el Preclásico tardío. Sin embargo, como la inundación se volvió más regular al final del periodo Preclásico, la región fue abandonada, solo para ser re-ocupada en el Postclásico tardío, cuando los humedales fueron explotados para recursos acuáticos, más que para la agricultura.

Palabras clave: Maya, agricultura de humedal, micromorfología, cambio paleoambiental, pedogénesis, geoarqueología. 


\section{Introduction}

The Yalahau region of northern Quintana Roo, Mexico (Figure 1), is defined by a network of 174 freshwater wetlands beginning at the north coast and extending south for approximately $50 \mathrm{~km}$ (Weidie, 1985; Fedick and Taube, 1995). This extensive freshwater wetland system represents a water-rich, biologically diverse ecosystem that stands in sharp contrast to the generally arid northern Yucatán Peninsula. The Yalahau Regional Human Ecology Project (YRHEP) has conducted archaeological and ecological research in the region since 1993 (Fedick and Taube, 1995). Research activities of the YRHEP include: a regional archaeological survey; detailed mapping of selected archaeological sites; excavation of ancient residential trash deposits; analysis of floral, faunal, and geological resources utilized; soil studies; ancient and modern agricultural practices; economic activities of the historical period; and environmental reconstruction (e.g., Mathews, 1998; Fedick et al., 2000; Morrison, 2000; Andersen, 2001; Rissolo, 2001; Rissolo et al., 2005; Fedick and Mathews, 2005; Glover, 2006; Rissolo and Mathews, 2006; Wollwage, 2008; Sedov et al., 2007, 2008; Sorensen, 2010; Solleiro-Rebolledo et al., 201 1; Glover, 2012; Wollwage et al., 2012; Chmilar, 2013; Leonard, 2013; Gust, 2016).

The Yalahau region is interesting for several reasons. First is the settlement history. Settlement studies in the Yalahau region indicate an atypical occupation history that saw initial settlement in the Middle Preclassic period (700-200 BC), widespread use of the region in the Late Preclassic/ Early Classic period (ca. 100 BC - AD 350/450), near abandonment of the region for the subsequent 800 years, and a smaller-scale reoccupation during the Postclassic period (AD 1200-1521; Fedick and Mathews, 2005; Rissolo et al., 2005; Glover and Stanton, 2010; Glover, 2012). The long Classic period abandonment of the Yalahau region is opposite the trend in neighboring areas, which saw Classic period political and demographic expansion of northern lowland polities such as Cobá to the south (Folan et al., 1983, 2009; Robles-Castellanos, 1990), Chikinchel to the west (Kepecs, 1998), and Ek Balám to the southwest (Bey et al., 1998).

Second is exploitation of wetlands. Initial research by Fedick et al. (2000), and more recent work by Leonard (2013) and Chmilar (2013), documented anthropogenic landscapes within the wetlands characterized by constructed rock alignments of various configurations in diverse physical settings within the wetland swales (figures 2 and 3). Twenty-six of approximately 174 wetlands have been surveyed to date, and 20 of the surveyed wetlands contain 516 rock alignments (for full details of the wetland surveys see Fedick, 1998a; Fedick et al., 2000; Leonard, 2013). Rock alignments are typically comprised of a single row of uncut limestone boulders and slabs; they range in length from 2 to $700 \mathrm{~m}$ (average $27 \mathrm{~m}$ ) and average $0.46 \mathrm{~m}$ wide by $0.25 \mathrm{~m}$ tall. The alignments were originally suggested to have functioned in ancient times to modify soil and hydrologic conditions, in order to increase the production of useful wetland resources or for agricultural purposes (Fedick, 1998b; Fedick et al., 2000; Andersen, 2001). Evidence for ancient Maya wetland agriculture is well known from northern Belize (Turner and Harrison, 1983; Lambert et al., 1984; Hammond et al., 1987; Pohl, 1990; Jacob, 1995; Berry and McAnany, 2007; Beach et al., 2009), southern Quintana Roo (Gliessman et al., 1983), and Campeche (Siemens and Puleston, 1972) but usually takes the form of canals and raised fields. The use of rock alignments in the Yalahau region therefore is a different type of wetland agro-engineering, and along with rock alignments/walkways recorded by Hixon (2011), is the only documented evidence for wetland manipulation in the northern Maya Lowlands.

Third is the issue of environmental change. There is abundant evidence from lake core studies and geoarchaeological excavations that the Maya were confronted with short and long term environmental change, as well as their own impacts on the landscape (Beach et al., 2015; Dunning et al., 2015). For example, dry periods at the end 


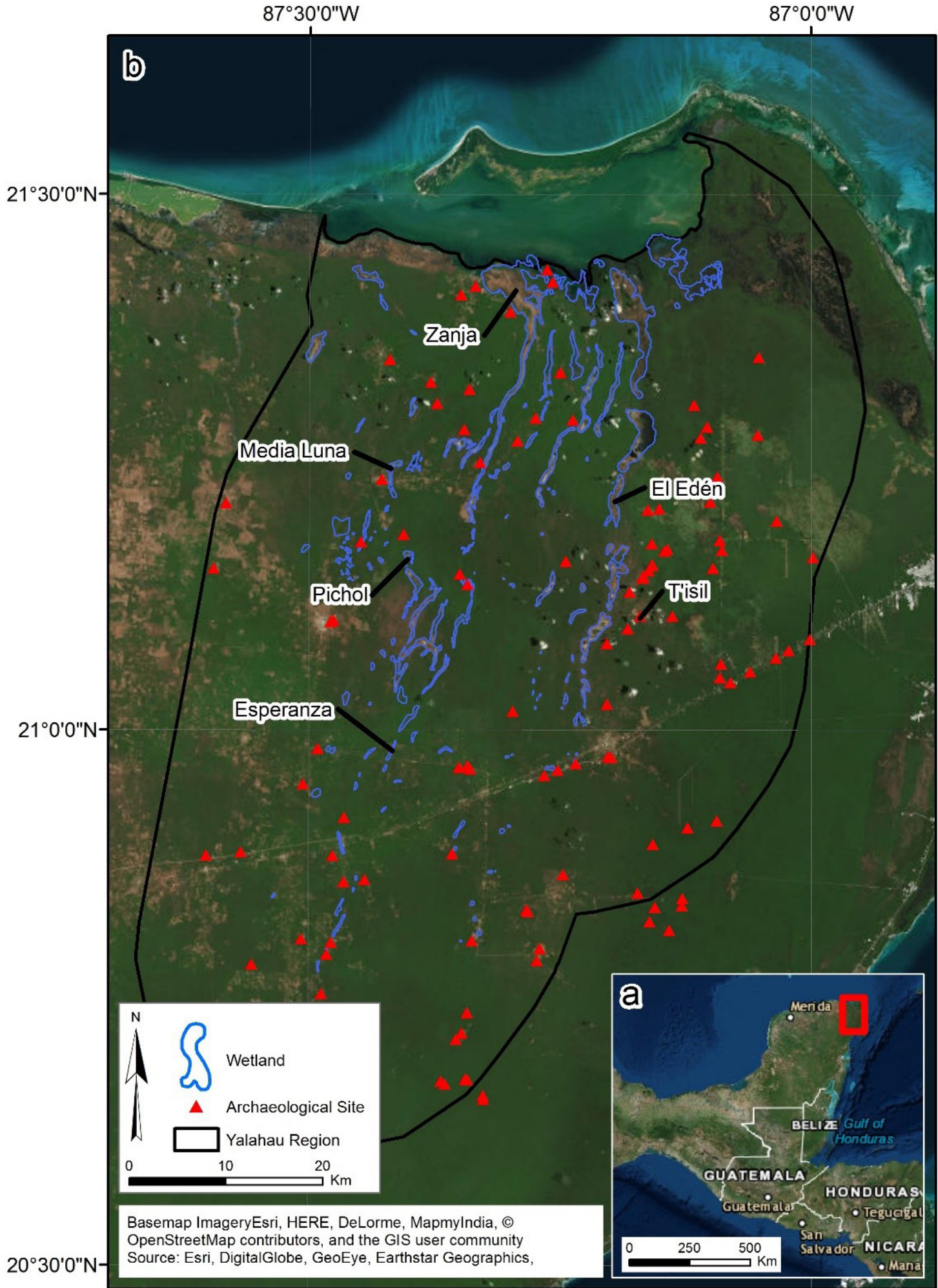

Figure 1 a) The Yucatan Peninsula of southeastern Mexico. Red square indicates the area represented in b). b) The Yalahau region (study area) showing Maya archaeological sites, wetlands, and sites mentioned in the text. El Edén and T'isil are two previously investigated locations that the current project builds on. Zanja, Media Luna, Pichol, and Esperanza are the current project study sites. 
of the Preclassic period are said to contribute to sociopolitical reorganization of this time (Carrillo-Bastos et al., 2010; Kennett et al., 2012; Douglas et al., 2015). Likewise, a series of droughts in the Terminal Classic coincides with abandonment of numerous large urban/civic centers (Hodell et al., 1995, 2001, 2005, 2007; Haug et al., 2003; Webster et al., 2007; Medina-Elizalde et al., 2010). In low lying coastal plain areas where the water table floats on a sea water intrusion (Perry et al., 2003), rising Holocene sea level (Fairbanks, 1989; Lambeck and Chappell, 2001; Toscano and MacIntyre, 2003) pushed up groundwater levels and caused increased flooding and soil aggradation in wetlands (Alcala-Herrera et al., 1994; Pope et al., 1996; Beach et al., 2009). In at least one case (Albion Island, Belize), continuing water table rise was cited as the cause for abandonment of farming in the Late Preclassic period (Pohl et al., 1990). "Maya clays" that accumulated in basins and lakes largely in the Preclassic period have been interpreted as evidence that a relatively small number of early farmers were responsible for a considerable amount of upland erosion due to deforestation, and the creation of anthropogenic soils within wetlands (Curtis et al., 1998; Hansen et al., 2002; Brenner et al., 2003; Beach et al., 2006; Dunning et al., 2006; Anselmetti et al., 2007).

In the Yalahau region, Fedick et al. (2000) suggested rising water levels may have impacted use of wetlands, and this in turn may have been a contributing factor in the Early Classic abandonment of the region (see also Wollwage, 2008; Wollwage et al., 2012; Fedick, 2014). This is supported by geoarchaeological investigations at the El Edén wetland (Figure 1), where one profile near the wetland edge shows modern wetland soil formation atop earlier dryland soils, indicating recent lateral expansion of this wetland (Solleiro-Rebolledo et al., 2011). Near the Yalahau coastal archaeological site of Vista Alegre, shallow water sediment cores indicated four sea level high stands that may have drowned freshwater springs along the coast and would have increased flood levels at inland wetlands (Beddows et al., 2016).

The El Edén reconstruction was based on a model of wetland soil development, initially described by Hodell et al. (2007: Figure 12), in which alternating bands of micritic muds and organic matter reflect periods of greater and lesser flooding

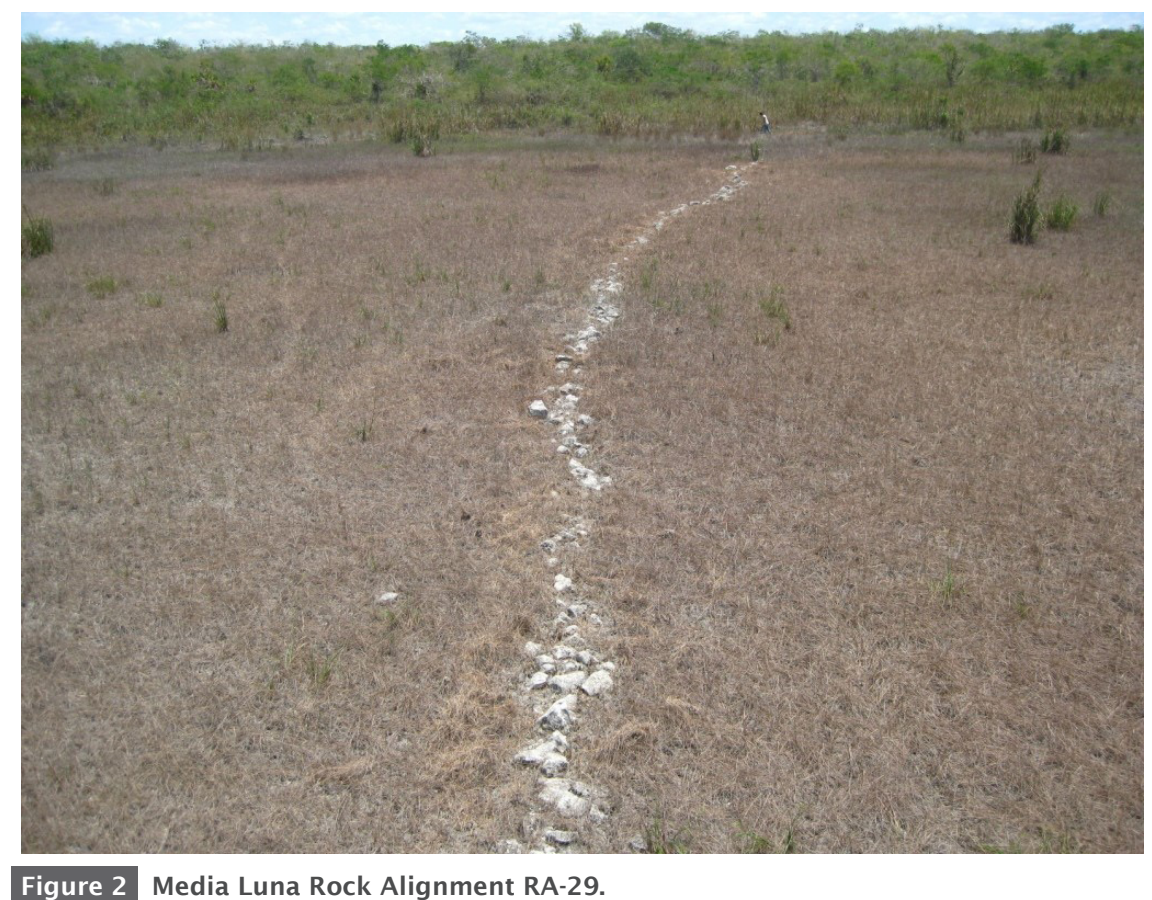


(Solleiro-Rebolledo et al., 2011). The soil horizons dominated by carbonates formed over periods (decade to century scale), probably during the Holocene (although no instrumental dating is available), when wetlands experienced regular annual flooding as they do today - flooded with 1-2 $\mathrm{m}$ of water for $\sim 7$ months out of the year (Figure 4). These micritic muds are a product of algae (periphyton), which form extensive mats when the wetland is flooded, and which precipitate micrite out of the carbonate-enriched floodwaters (Sedov et al., 2007, 2008). Organic-dominated horizons, alternatively, formed during periods of less flooding (Hodell et al., 2007; Solleiro-Rebolledo et al., 2011). In these environmental conditions, algal activity is suppressed and the soil formation process is controlled more by the growth, death, and decomposition of rooting plants (Hodell et al., 2007).

It is in this context of complex interplay of humanand natural-induced environmental impacts that this study considers the use and abandonment of wetland farming in the Yalahau region. Of particular interest is how changing flood patterns in the wetlands relate to the Early Classic abandonment of the Yalahau region. The aim of this work is to use the El Edén soil sequence, and the model used to explain it (Hodell et al., 2007: Figure 12; Solleiro-Rebolledo et al., 2011; see Figure 4), as the basis for interpreting the timing and nature of changing hydrologic conditions at other wetlands in the region. This in turn will provide a context for understanding Maya use of wetlands and cycles of settlement and abandonment of the region. Five wetland soil-sediment profiles from across the region are studied - with analysis focused on soil micromorphology.

\section{Materials and methods}

\subsection{ENVIRONMENTAL SETTING}

The Yalahau region is located in northern Quintana Roo, Mexico (Figure 1), and covers approximately $3000 \mathrm{~km}^{2}$. The region is defined by a large network of freshwater wetlands that form within long, north-south trending depressions beginning at the north coast and continuing for at least $50 \mathrm{~km}$ south (Weidie, 1985).

The limestone platform of the Yucatan Peninsula consists of Early Cretaceous deposits, Middle Cretaceous deposits in the central and northern portions, and Cenozoic limestones up to 1200 meters thick (Weidie, 1985). The heavily karstified surface geology of the Yalahau region, and of the northern and eastern margin of the Yucatan Peninsula in general, consists of Miocene/Pliocene deposits (upper Tertiary) and coastal Holocene deposits of the Carillo Puerto Formation (Lauderdale et al., 1979; Rebolledo-Vieyra et al., 2000; Purdy et al., 2003; SGM, 2007; Gondwe et al., 2010). The Carillo Puerto Formation averages about 13 meters in thickness, and consists of poorly consolidated coquina, interbedded with calcarenite, capped with a caliche crust (Rebolledo-Vieyra et al., 2000). The wetlands that characterize the Yalahau region are surface dissolution features reflecting the structure of the underlying Holbox Fracture Zone (Tulaczyk, 1993). This fracture zone is of undefined origin, but the faults are thought to create exceptionally permeable features that act as channels for groundwater movement (Weidie, 1985; Perry et al., 2003). The approximately 174 wetlands range in size from about $0.005 \mathrm{~km}^{2}$ to $8 \mathrm{~km}^{2}$ (three wetlands exceed this, the largest, an extremely long wetland, being $31 \mathrm{~km}^{2}$ ) that cover an area of about $134 \mathrm{~km}^{2}$ (Fedick and Mathews, 2005). The region also contains over 100 cenotes, limestone sinkholes that typically reach the water table (Bell, 1998; Glover, 2006). Water found in wetlands and cenotes represents exposure of the water table (Tulaczyk, 1993). The aquifers of the northern Yucatan Peninsula have developed in the highly permeable rock dominated by Tertiary limestones and dolostones (Perry et al., 2003). The freshwater aquifers of the northern peninsula are underlain by a seawater intrusion, and as a result, the surface elevation of the water table is primarily controlled by sea level (Perry et al., 2003). 
Soils of the Yalahau region include Rendzinc Leptosols in upland areas and Leptic Calcisols in wetlands (Sedov et al., 2008; Solleiro-Rebolledo et al., 2011). The wetland Calcisols are shallow and include substantial amounts of secondary carbonates, contrary to the usual image of wetlands containing thick deposits of organic peats and gleys. The relief is flat with altitudes $<20 \mathrm{~m}$ asl (LugoHubp et al., 1992), although there is an absolute difference in elevation of $1.93 \mathrm{~m}$ (Charvet, 2009). Average annual rainfall is $1295.8 \mathrm{~mm}$, about $75 \%$ of which falls during a rainy season from May to October (Comisión Nacional del Agua, 2008). During the dry season from November to April, wetlands appear as open grasslands - soil may be moist but water is generally restricted to small ponds and lagoons within wetlands. During the rainy season, wetlands typically flood with $1-2 \mathrm{~m}$ of water. The upland forests of the region are characterized as dry tropical medium-statured, with notable species including chico zapote (Manilkara zapota), black chechem (Metopium brownei), gumbo limbo (Bursera simaruba), and guano palm (Thrinax radiata). Wetlands include both swamp forests dominated palo tinto (Haematoxylum campechianum), and large open areas dominated by sedges such as sawgrass (Cladium jamaicense) and spikerushes (Eleocharis sp.) (Schultz, 2003).

\subsection{FIELDWORK}

Over the course of fieldwork between 2010 and 2011, 30 soil profiles were sampled across 12 wetlands. From these 30 profiles, 5 were selected that represent the following criteria: the range of thicknesses of the soil-sediment layer, the range of types of surface soil horizons and buried soil horizons, and a variety of landscape positions within wetlands (some of which are spatially related to rock alignments). The 5 profiles included in this study come from four wetlands: Zanja (2 profiles), Esperanza, Media Luna, and Pichol (Figure 5). In the case of Zanja, Esperanza, and Media Luna, sediment cores were extracted using $7.62 \mathrm{~cm}$ PVC

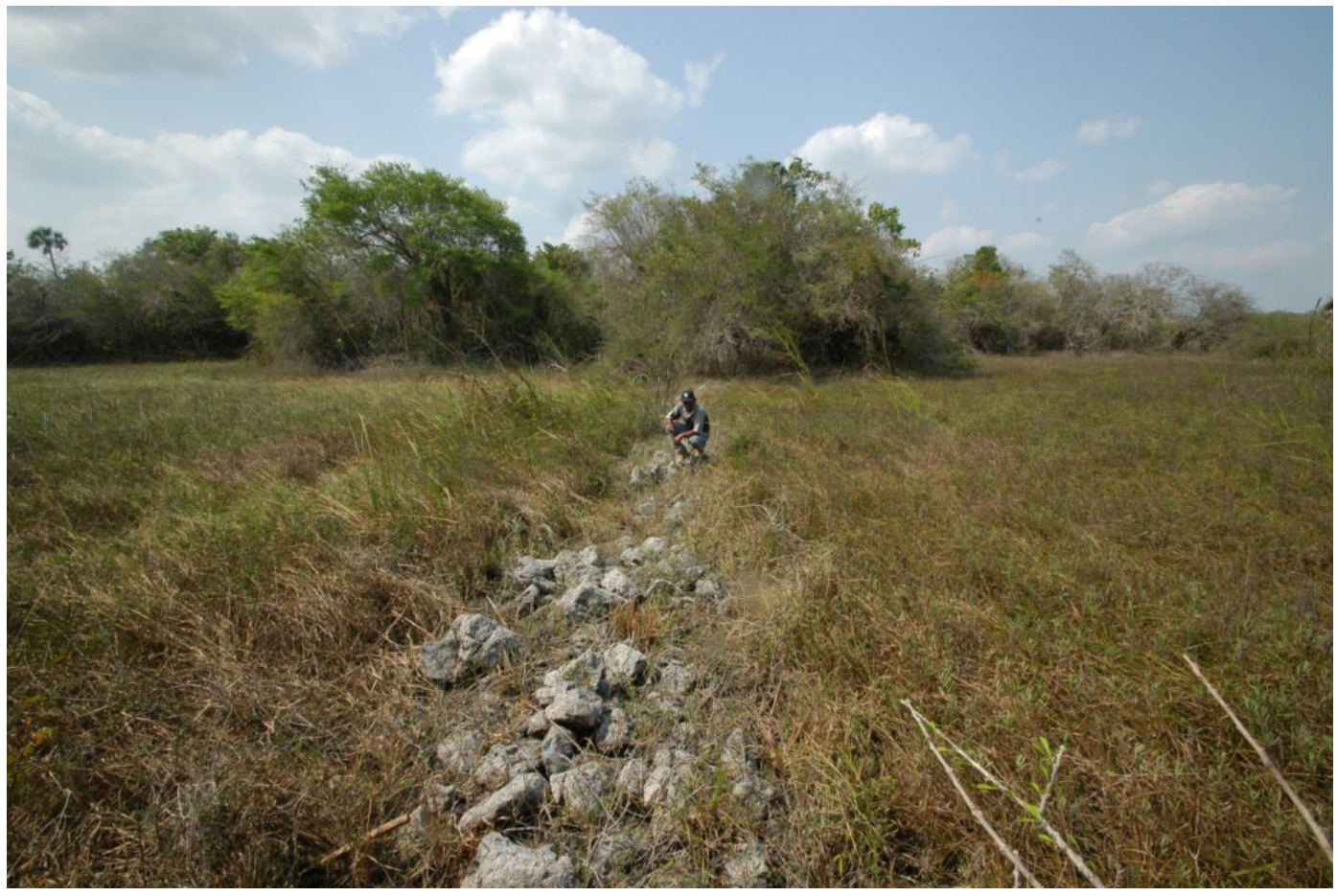

Figure 3 Pichol Rock Alignment RA-32. 

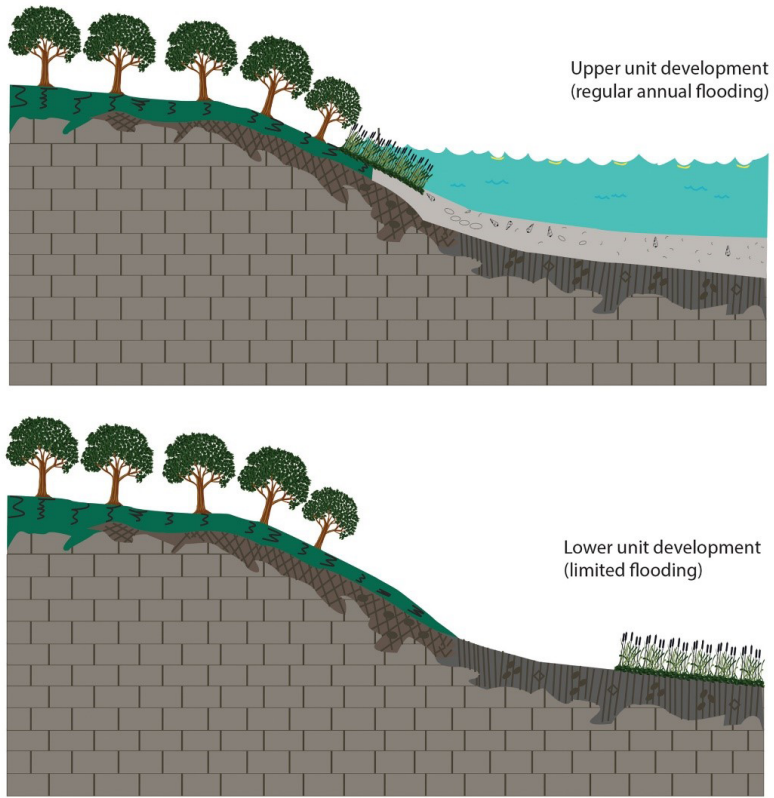

LEGEND

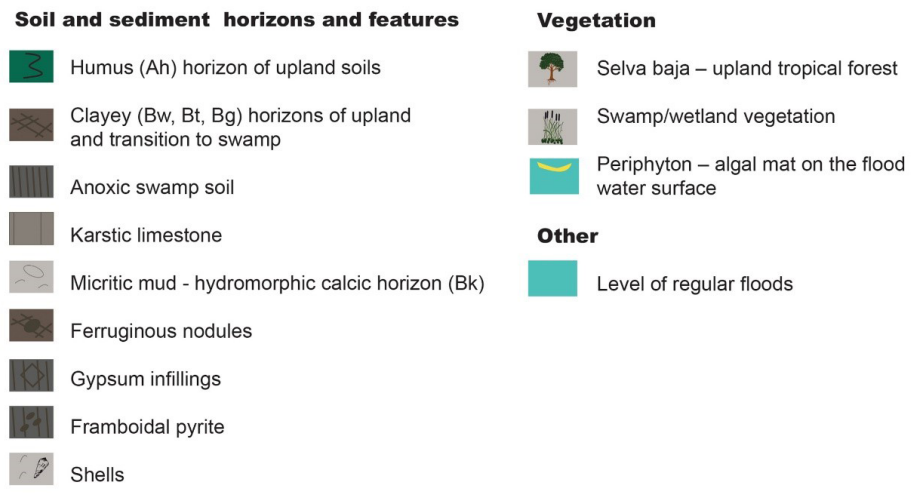

Figure 4 Schematic showing the wetland soil development model.

pipe manually pushed into the ground. At Pichol, a soil pit was excavated and stratigraphy was described and sampled in situ.

\subsection{PROFILE LOGATIONS}

The Zanja SP-1 core $\left(87^{\circ} 17^{\prime} 50^{\prime \prime} \mathrm{W}, 21^{\circ} 24^{\prime} 24^{\prime \prime N}\right)$ was retrieved from a relatively low elevation position near the center of the wetland dominated by sawgrass vegetation (Figure 1). Water was encountered at $0.10 \mathrm{~m}$ below surface and soil depth to bedrock was greater than $6 \mathrm{~m}$ (measured using a soil probe). The core was inserted to a depth of 1.6 $\mathrm{m}$ below surface and the compacted core length was $0.98 \mathrm{~m}$. Periphyton was not observed on the surface here. Only one rock alignment was identified at the Zanja wetland, and it is located nearly $20 \mathrm{~km}$ south of the SP-1 core location.

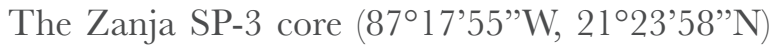
was retrieved from a relatively high elevation position at the west edge of the wetland with calabash (Crescentia sp.) and tasiste (Acoelorraphe wrightii) vegetation (Figure 1). Water was encountered at $0.18 \mathrm{~m}$ below surface and soil depth to bedrock was $0.38 \mathrm{~m}$. The core was inserted to bedrock with no soil compaction. Periphyton was not observed 
on the surface here. Only one rock alignment was identified at the Zanja wetland, and it is located nearly $20 \mathrm{~km}$ south of the SP-3 core location.

The Esperanza SP-2 core $\left(87^{\circ} 25^{\prime} 05^{\prime} \mathrm{W}\right.$, $20^{\circ} 58^{\prime} 44^{\prime} \mathrm{N}$ ) was retrieved from a relatively low elevation position in the wetland dominated by Scirpus sp. vegetation (Figure 1). Water was encountered at $0.55 \mathrm{~m}$ below surface and soil depth to bedrock was $2.1 \mathrm{~m}$. The core was inserted to a depth of $1.2 \mathrm{~m}$ and the compacted core length was $1.1 \mathrm{~m}$. Periphyton was present on the surface. Three rock alignments were recorded at Esperanza. Alignment RA-1 is located $30 \mathrm{~m}$ north of the SP-2 core.

The Media Luna SP-1 core $\left(87^{\circ} 25^{\prime} 05^{\prime \prime} \mathrm{W}\right.$, $\left.21^{\circ} 14,54^{\prime \prime} \mathrm{N}\right)$ was retrieved from a relatively low-intermediate elevation position dominated by spikerush (Eleocharis sp.) vegetation (Figure 1). Water was encountered at $0.15 \mathrm{~m}$ below surface and soil depth to bedrock was $1.21 \mathrm{~m}$. The core was inserted to a depth of $1 \mathrm{~m}$ and the compacted core length was $0.67 \mathrm{~m}$. Periphyton was present on the surface. Sixty-two rock alignments were recorded at Media Luna. The closest alignment to the SP-1 core is $25 \mathrm{~m}$ away, with many other rock alignments in the vicinity (Figure 6). The general distribution of rock alignments in this wetland shows alignments located near the margins of the open wetland, frequently connecting groups of topographic rises.

The Pichol SP-2 profile pit (87'24'00'W, $21^{\circ} 09^{\prime} 56^{\prime} \mathrm{N}$ ) was excavated in a relatively intermediate elevation position in the wetland with sedge (Scirpus sp.) vegetation (Figure 1). Water was not encountered and soil depth to bedrock was 0.52 $\mathrm{m}$. The soil pit was excavated down to bedrock. Periphyton was present on the surface. Fifty-four rock alignments were recorded at Pichol. SP-2 was excavated $5 \mathrm{~m}$ from rock alignment RA-32, and numerous other alignments are in the vicinity. Similar to Media Luna, rock alignments at Pichol are found near the margins of the open wetland, connecting small bedrock islands.

\subsection{LABORATORY ANALYSES}

The cores and field samples were sent to the labs of Dr. Sedov and Dr. Solleiro-Rebolledo, Institute of Geology at the Universidad Nacional Autónoma de México, where they were opened, photographed, described, and sampled. Immediately upon opening the cores, it was clear the soils represented a highly heterogeneous system. The horizons were separated and designated according to the IUSS Working Group (2015).

Morphological and micromorphological analyses were applied to all cores. Thin sections were prepared from undisturbed samples taken at the time cores were opened, then observed and described with an Olympus petrographic microscope. Plane polarized light, crossed polarized light, and occasionally reflected light, was used to observe micromorphological features in the thin sections. Three cores (Zanja SP-1, Esperanza SP-2, and Media Luna SP-1) were selected for instrumental dating. Ten radiocarbon dates were run on bulk organic sediment from these 3 cores (Figure 7, Table 1). The radiocarbon samples were processed at the University of Arizona Accelerator Mass Spectrometry Laboratory and the University of California Irvine W. M. Keck Carbon Cycle Accelerator Mass Spectrometry (AMS) Laboratory. Radiocarbon date calibration was computed using the IntCal09 dataset and CABLIB 6.0 software package (Stuiver et al., 2013).

\section{Results}

\subsection{MAGROMORPHOLOGY}

Macromorphologically, all profiles can be divided into an upper and lower unit (Figures 8 and 9). The upper units are fairly similar to one another, while the lower units are quite variable. The upper units of Zanja SP-1 and Esperanza SP-2 are characterized by alternating layers of whitish 


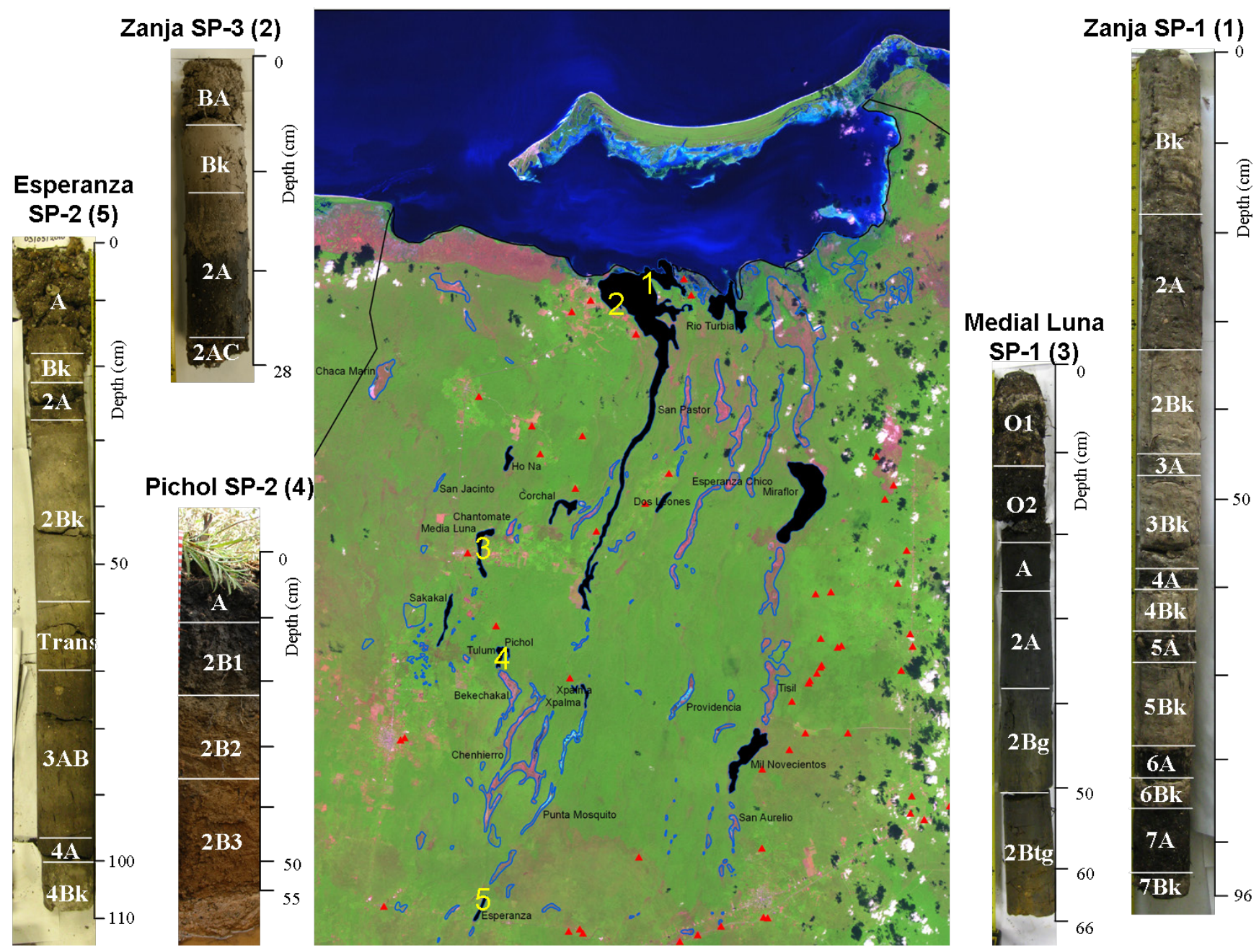

Figure 5 Five cores selected for study, and their locations and horizon designations. Note: in Esperanza SP-2, the "Trans" horizon stands for "Transition".

carbonate material and dark material enriched in organic matter. Shells are common in these layers and even the organic layers incorporate carbonates. The upper units of Media Luna SP-1, Pichol SP-2, and Zanja SP-3 display both humified and poorly decomposed organic matter mixed with carbonates and some shells.

In Media Luna, Pichol, and Zanja SP-3, lower unit soils exhibit clayey texture, little to no carbonates, and well-decomposed organic matter (proto-humus in some cases). The Zanja SP-1 lower unit has a slight reaction to $\mathrm{HCl}$, some shells, and organic matter is mostly proto-humus. The structure is massive, breaking into angular blocks. The
Esperanza SP-2 lower unit is white in color, has shells and a strong reaction to $\mathrm{HCl}$, and also has a massive structure that breaks into angular blocks. Macroscopically, therefore, the lower and upper units of Zanja SP-1 and Esperanza SP-2 show similar morphology.

According to the WRB (IUSS Working Group WRB, 2015), a horizon designation was established in each unit (Figure 5).

The upper unit of Media Luna SP-1 profile has O1 $(0-12 \mathrm{~cm}), \mathrm{O} 2(12-21 \mathrm{~cm})$, and A $(21-27 \mathrm{~cm})$ horizons; while the lower unit shows the following horizons: 2A (27-39 cm), 2Bg (39-51 cm), 2Btg $(51-66 \mathrm{~cm})$. 


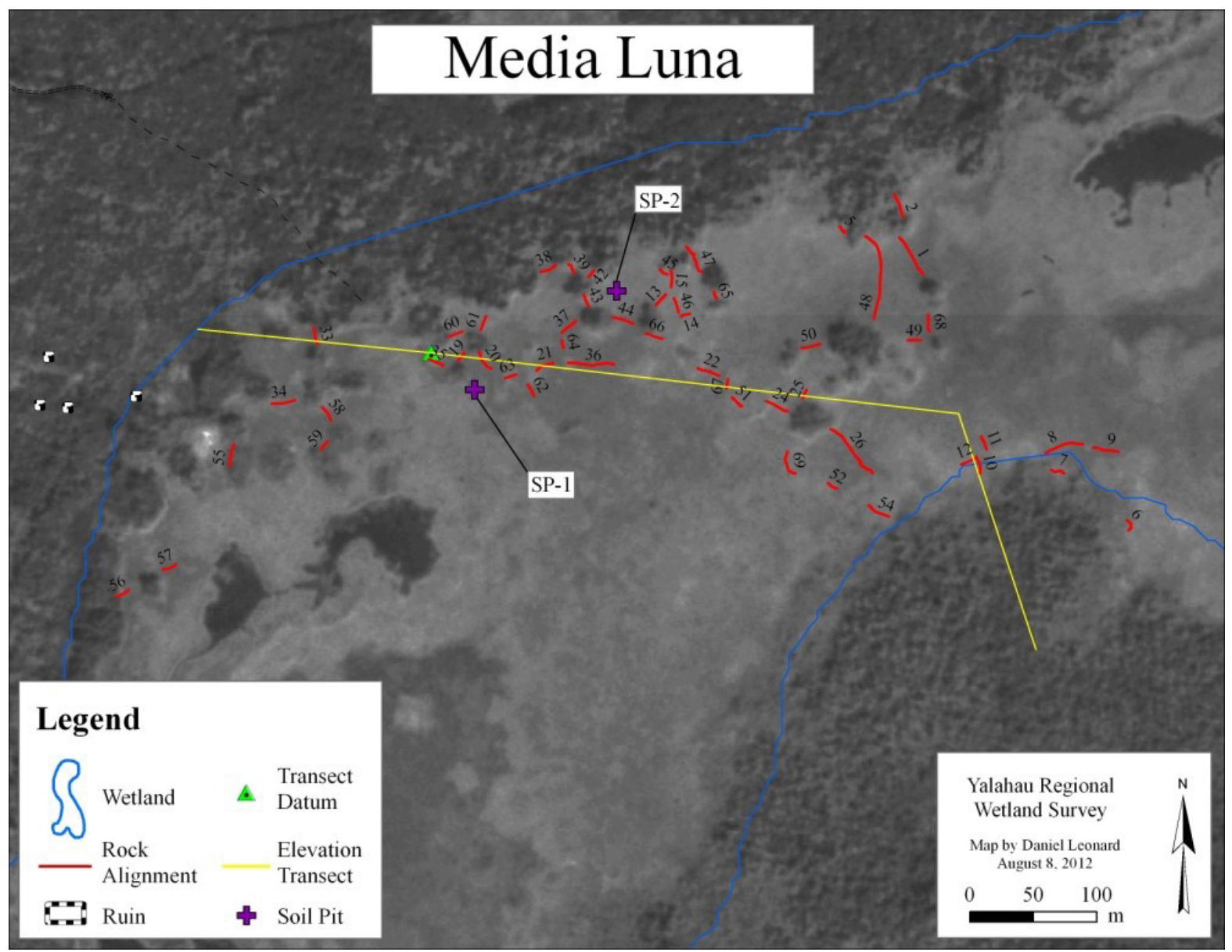

Figure 6 Media Luna wetland showing locations of rock alignments and soil profiles. The elevation transect is part of the larger study but not discussed in this paper.

Pichol SP-2 profile is constituted by A $(0-10 \mathrm{~cm}$, the upper unit), 2B1 (10-20 cm), 2B2 (20-32 cm), and $2 \mathrm{~B} 3(32-55 \mathrm{~cm})$ horizons.

The Zanja SP-3 upper unit has BA and Bk horizons $(0-4 \mathrm{~cm}, 4-11 \mathrm{~cm}$, respectively). The lower unit exhibits $2 \mathrm{~A}(11-28 \mathrm{~cm})$ and $2 \mathrm{C}(>28 \mathrm{~cm})$ horizons.

Esperanza SP-2 has in the upper unit A $(0-19 \mathrm{~cm})$, $\mathrm{Bk}(19-22 \mathrm{~cm}), 2 \mathrm{~A}(22-30 \mathrm{~cm}), 2 \mathrm{Bk}(30-61 \mathrm{~cm})$, a transitional layer $(61-71 \mathrm{~cm}), 3 \mathrm{AB}(71-100 \mathrm{~cm})$, and $4 \mathrm{~A}(100-105 \mathrm{~cm})$ horizons. The lower unit is only constituted by the $4 \mathrm{Bk}$ horizon $(>105 \mathrm{~cm})$.

The Zanja SP 1 upper unit has the following horizons: $\mathrm{Bk}(0-18 \mathrm{~cm}), 2 \mathrm{~A}(18-34 \mathrm{~cm}), 2 \mathrm{Bk}(34-46)$, $3 \mathrm{~A}(46-48 \mathrm{~cm}), 3 \mathrm{Bk}(48-58 \mathrm{~cm}), 4 \mathrm{~A}(58-61 \mathrm{~cm})$,
4Bk $(61-66 \mathrm{~cm}), 5 \mathrm{~A}(66-68 \mathrm{~cm}), 5 \mathrm{Bk}(68-79 \mathrm{~cm})$, $6 \mathrm{~A}(79-84 \mathrm{~cm}), 6 \mathrm{Bk}(84-85 \mathrm{~cm})$. The lower unit of Zanja SP-1 is represented by the $7 \mathrm{~A}$ and $7 \mathrm{Bk}$ horizons at a depth of 89-96 cm below surface.

\subsection{MICROMORPHOLOGY OF THE UPPER UNITS}

The main micromorphological components of the upper units are biogenic micrite, sparite, freshwater mollusk shells, and organic matter in the form of partly decomposed fragments of plant tissues (colloidal organic material) (figures 10a and 10b). They are found in the upper units of all cores, however, proportions vary. In the organic horizons, for instance in the $\mathrm{O} 1$ and $\mathrm{O} 2$ horizons of 
the Media Luna SP-1 profile, plant residues with intact cellular structure are observable; some pores of these residues are filled with micrite (figures 10c and $10 \mathrm{~d}$ ). In the calcic horizons (e.g., 3Bk horizon of the Zanja SP-1) complete shells are found in a micritic groundmass locally containing dark organic pigment (figures 10e and 10f). These components reflect the modern seasonal flood regime.

\subsection{MICROMORPHOLOGY OF THE LOWER UNITS}

\subsubsection{MEDIA LUNA SP-1}

The 2A horizon is characterized by organic matter and clay, with no observable carbonates (Figure 11a). The groundmass is very fine, with some relatively large charcoal particles. Frequent infillings of tabular gypsum crystals were observed in cracks around the groundmass (figures $11 \mathrm{~b}$ and 11c). Localization in the pores (while unobserved in the groundmass inside the peds), as well as perfect crystalline shape, point to gypsum neoformation. Development of gypsic pore pedofeatures is frequently associated with evaporation of gypsum-saturated groundwater (Poch et al., 2010). The key point is that gypsum is 10 times more soluble than carbonates. Thus, in these environmental conditions it is very rare for gypsum to remain undissolved in crystal form. The presence of gypsum therefore may indicate drier past conditions. However, infillings of neoformed gypsum are also known to be the oxidation product of pyrite (Miedema et al., 1974). In this case it could be related to the aeration of swampy soils where pyrite was formed earlier under anoxic conditions due to fluctuation of the water table. This latter scenario does not necessarily imply strong aridization. The discovery of framboidal pyrite in the lower unit of Esperanza SP-2 supports this version.

The 2Bg and 2Btg horizons are characterized by a clay groundmass with a patchy color pattern; pale clayey areas alternating with rusty brown ferruginous mottles points to the redistribution of iron, due to gleyzation processes (Figure 11d).

\subsubsection{ZANJA SP-1}

The 7A horizon shows a high concentration of organic matter, a large part of which has been converted to "protohumus" - dark collomorphic material showing no or weak remains of cellular structure (although some pieces have tissue morphology). The groundmass includes areas impregnated with organic matter with frequent small cracks and pores, as well as a few large cracks. Other areas of the groundmass with more carbonates show medium-compact blocks separated by fractures. Unlike in the upper units, the calcite is mostly sparitic, and shell content is high. The interpretation of the lower unit of Zanja SP-1 is that organic matter had time for considerable decomposition - this implies at least some periods of an oxidative soil environment and limited flooding.

\subsubsection{ZANJA SP-3}

Although the 2A horizon has less carbonates compared with the overlying $\mathrm{Bk}$ horizon (see upper unit description), there is much more organic matter here, and it is highly decomposed. In some places, there are sparitic carbonate nodules or larger crystals as well as micritic nodules. The most important soil feature in the lower unit here, however, is the area with large anhedral calcite crystals forming compact infillings (figures 12a and 12b). Solleiro-Rebolledo et al. (2011) published similar results from peripheral polygenic profiles at El Edén where carbonates were found filling pores and cementing aggregates enriched with humus. Such coarse-grained cement of interlocking calcite crystals is typical for the phreatic environment (Durand et al., 2010). These carbonates are very different from those formed by wetland floods with algae - instead, they grow slowly under permanent saturation by groundwater.

\subsubsection{ESPERANZA SP-2}

In the $4 \mathrm{Bk}$ horizon micrite was not observed; carbonate is mostly in the form of sparitic calcite 
crystals (sand-size) that are well spread out and evenly distributed. The crystals have a well-defined shape, indicating they were formed in situ. Some crystals display etched pits - a dissolution feature. This indicates a highly dynamic horizon where calcite is neoformed but also dissolved (after being neoformed/precipitated). Mollusk shells are present but most are fragmented. Some organic matter is present, appearing as small dark dots (humus punctuations). A few loose infillings of black globular particles that are orange and gold under reflected light represent neoformed pyrite (framboidal crystals), pointing to an anoxic, permanently water-saturated environment (figures $12 \mathrm{c}$ and $12 \mathrm{~d}$ ).

\subsubsection{PICHOL SP-2}

The $2 \mathrm{~B} 1$ horizon is characterized by nearly pure clay material, pale yellow in color - depleted of ferruginous pigment - due to gleying. The groundmass is compact in general, but some pores and channels occur, as do a few excrements of mesofauna (species undetermined). Some humus pigmentation is mixed with clay, and some
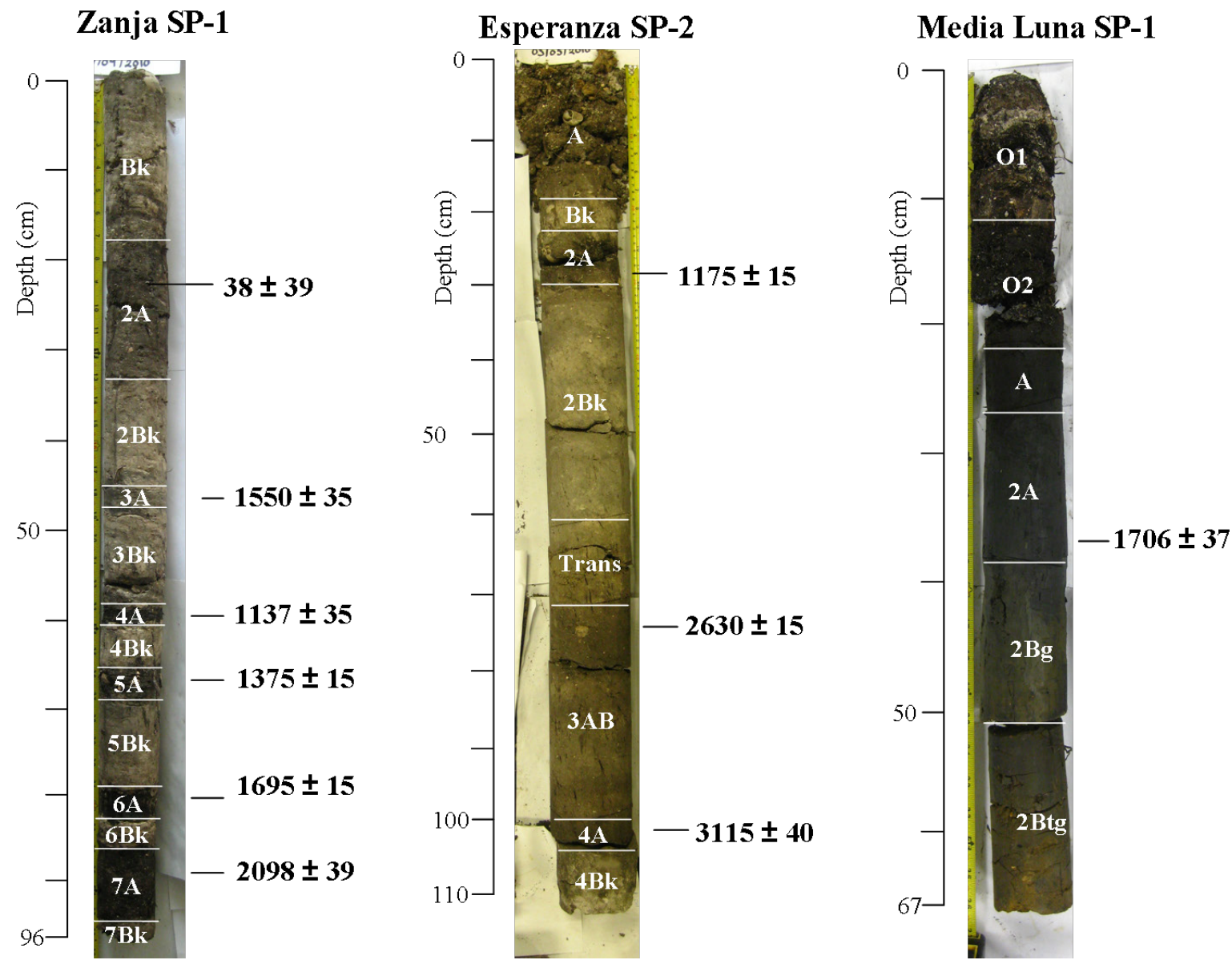

Figure 7 Three soil cores showing horizon designations and radiocarbon dates in 14C years BP. Note: in Esperanza SP-2, the "Trans" horizon stands for "Transition". 
Table 1. Results of AMS dating of organic-rich soil from wetland cores.

\begin{tabular}{|c|c|c|c|c|c|c|}
\hline Lab ID & $\begin{array}{l}\text { Depth } \\
(\mathrm{cm})\end{array}$ & Material & $\delta^{13} \mathrm{C}$ & ${ }^{14} \mathrm{C}$ Age BP & $\begin{array}{c}\text { Age } \\
\text { Cal BP }\end{array}$ & $\begin{array}{c}2 \sigma \text { Calibrated Age } \\
\text { Ranges }\end{array}$ \\
\hline \multicolumn{7}{|l|}{ Zanja Core 1} \\
\hline AA 92181 & 24 & $\begin{array}{l}\text { org-rich } \\
\text { soil }\end{array}$ & -27.2 & $38 \pm 39$ & $51 \pm 82$ & $\begin{array}{l}\text { AD } 1692-1728(\mathrm{p}=.231) \\
\text { AD } 1811-1920(\mathrm{p}=.725) \\
\text { AD 1952- } 1955(\mathrm{p}=.045)\end{array}$ \\
\hline UCIAMS 104165 & 47 & $\begin{array}{l}\text { org-rich } \\
\text { soil }\end{array}$ & * & $1550 \pm 15^{* *}$ & $1457 \pm 42 * *$ & $\begin{array}{l}\text { AD 432-495 }(\mathrm{p}=.605) \\
\text { AD 503-560 }(\mathrm{p}=.395)\end{array}$ \\
\hline AA 92182 & 59 & $\begin{array}{l}\text { org-rich } \\
\text { soil }\end{array}$ & -27.8 & $1137 \pm 35$ & $1050 \pm 53$ & $\begin{array}{l}\text { AD 781-791 }(\mathrm{p}=.026) \\
\text { AD 807-986 }(\mathrm{p}=.974)\end{array}$ \\
\hline UCIAMS 104167 & 67 & $\begin{array}{l}\text { org-rich } \\
\text { soil }\end{array}$ & * & $1375 \pm 15$ & $1375 \pm 15$ & AD 643-667 $(p=1)$ \\
\hline UCIAMS 104168 & 79 & $\begin{array}{l}\text { org-rich } \\
\text { soil }\end{array}$ & * & $1695 \pm 15$ & $1595 \pm 23$ & $\begin{array}{l}\text { AD 260-283 }(\mathrm{p}=.129) \\
\text { AD 323-407 }(\mathrm{p}=.871)\end{array}$ \\
\hline AA 92183 & 88 & $\begin{array}{l}\text { org-rich } \\
\text { soil }\end{array}$ & -27.6 & $2098 \pm 39$ & $2073 \pm 51$ & $\begin{array}{l}344-323 \mathrm{BC}(\mathrm{p}=.025) \\
205-37 \mathrm{BC}(\mathrm{p}=.955) \\
30-21 \mathrm{BC}(\mathrm{p}=.009) \\
11-2 \mathrm{BC}(\mathrm{p}=.011)\end{array}$ \\
\hline \multicolumn{7}{|l|}{ Esperanza Core 2} \\
\hline UCIAMS 104164 & 30 & $\begin{array}{l}\text { org-rich } \\
\text { soil }\end{array}$ & $*$ & $1175 \pm 15$ & $1107 \pm 33$ & $\begin{array}{l}\text { AD 779-794 }(\mathrm{p}=.106) \\
\text { AD 798-894 }(\mathrm{p}=.886) \\
\text { AD 929-932(p=.007) }\end{array}$ \\
\hline UCIAMS 104166 & 74 & $\begin{array}{l}\text { org-rich } \\
\text { soil }\end{array}$ & * & $2630 \pm 15$ & $2757 \pm 5$ & $815-793$ BC $(p=1)$ \\
\hline AA 92179 & 99 & $\begin{array}{l}\text { org-rich } \\
\text { soil }\end{array}$ & -26.9 & $3115 \pm 40$ & $3332 \pm 48$ & $\begin{array}{l}1493-1476 \text { BC }(\mathrm{p}=.025) \\
1460-1292 \text { BC }(\mathrm{p}=.968) \\
1277-1272 \text { ВC }(\mathrm{p}=.007)\end{array}$ \\
\hline \multicolumn{7}{|l|}{ Media Luna Core 1} \\
\hline AA 92180 & 37 & $\begin{array}{l}\text { org-rich } \\
\text { soil }\end{array}$ & -28.7 & $1706 \pm 37$ & $1627 \pm 54$ & AD $248-413(p=1)$ \\
\hline
\end{tabular}

*Dates are corrected for isotopic fractionation but $\delta^{13} \mathrm{C}$ values are not reported to clients.

*:Date represents an age reversal and is excluded from analysis.

decomposed organic particles (nearly humus) are incorporated into the groundmass. In some places, there are large ferruginous nodules, indicating redistribution of iron. A large round iron oxide nodule with clear concentric growth rings indicates that it is growing in situ (figures 12e and 12f). Rounded ferruginous concretions are a common feature of the lower unit horizons of Pichol SP-2. Horizon 2B2 is compact and clayey, with some brown ferruginous pigment - fine iron oxides mixed with clay result in this color. There are also signs of gleyzation - some iron nodules and areas with paler color. However, it was not saturated permanently since the horizon is only partially gleyed. No carbonates (including shells) or gypsum were observed in the $2 \mathrm{~B} 2$ horizon.

Horizon 2B3 is similar to the above, but the gleyzation is stronger and ferruginous nodules and concretions are more abundant. This horizon also lacks micritic carbonates and shells, similar to 
those horizons observed in the well-drained soils in the uplands of the adjacent forest, as reported by Sedov et al. (2007, 2008). Therefore, this soil layer formed under semi-hydromorphic, semi-swampy conditions (while the soil in Esperanza SP-2 [4Bk horizon] with pyrite was permanently saturated).

\subsection{GHRONOLOGICAL FRAME OF THE STUDIED PROFILES}

Ten radiocarbon dates were collected from 3 different cores that span the past 3332 years cal BP (Table 1; see Figure 7). Due to the absence of identifiable charcoal or other reliably ancient organic materials, all dates were run on bulk organic sediment. The Zanja core is the most well-stratified sequence, with 6 dates ranging from $2073 \pm 51$ cal BP ([AA 92183] 205-37/344-323/11-2/30-21 $\mathrm{BC})$ at the base of the core to $51 \pm 82 \mathrm{cal} \mathrm{BP}$ ([AA 92181] AD 1811-1920/1692-1728/1952-1955) near the top. Aside from the date of $1457 \pm 42 \mathrm{cal}$ $\mathrm{BP}$ at a depth of $47 \mathrm{~cm}$ ([UCIAMS 104165] AD 432-495/503-560), the radiocarbon dates from Zanja SP-1 are in chronological order. Three dates from Esperanza SP-2 range from $3332 \pm 48 \mathrm{cal} \mathrm{BP}$ ([AA 92179] 1460-1292/1493-1476/1277-1272 $\mathrm{BC}$ ) to $1107 \pm 33 \mathrm{cal} \mathrm{BP}$ ([UCIAMS 104164] AD 798-894/779-794/929-932) and are in chronological order. A single determination [AA 92180] from Media Luna SP-1 dates $1627 \pm 54$ cal BP (AD 248-413). We acknowledge that relying on a single date from Media Luna is problematic, and recognize there is a need for further dating of the site.

\section{Discussion}

\subsection{UPPER VS. LOWER UNITS}

The macroscopic and microscopic results clearly show the separation of the cores into two major units (see figures 8 and 9). Similar to the soils studied at El Edén (Solleiro-Rebolledo et al., 2011), the upper units show an alteration of fine carbonates and organic materials, as well as shell. Under the microscope, the fine carbonates are mostly micritic, and the organic matter is mainly detritus (intact plant fragments) with some humified parts or protohumus substance. As described by Hodell et al. (2007) and Solleiro-Rebolledo et al. (2011), the micritic muds identify flooding events because algae responsible for micrite precipitation only develop on the water surface. Organic materials, on the other hand, mostly come from higher/rooting plants, which may tolerate some flooding, but mostly develop under conditions of less flooding. The lower units demonstrate a great variety of features and formation processes (despite appearing similar macromorphologically). Micromorphological examination of soil thin sections identified gley properties, highly organic materials with coarse-grained calcite, gypsum neoformation, and in one case, in the 4Bk horizon of Esperanza SP-2, precipitation of pyrite (figures 12c and 12d). None of the lower units have micritic muds, and it is therefore concluded that they were not flooded for any significant periods of time. All of the lower units, however, show signs of water saturation and swampy pedogenesis. There is evidence of gleyzation with the accumulation of organic matter (mostly well decomposed) that is partly mixed with clay. Also present are neoformed minerals that also show a hydrogenic origin. Pyrite can be formed only in a very anoxic environment, thus in water-saturated (i.e. reduced) contexts. If exposed to oxygen, pyrite forms iron oxide, and if it interacts with sulfuric acid, it can form gypsum (Miedema et al., 1974; Poch et al., 2010).

Coarse-grained carbonate crystals are typical of hydrogenic carbonates precipitated from groundwater. They are not biogenic, and grow slowly under permanent saturation by groundwater. Conditions in the wetland during formation of the lower unit therefore appear to have been swampy, but with limited flooding. This formation process 


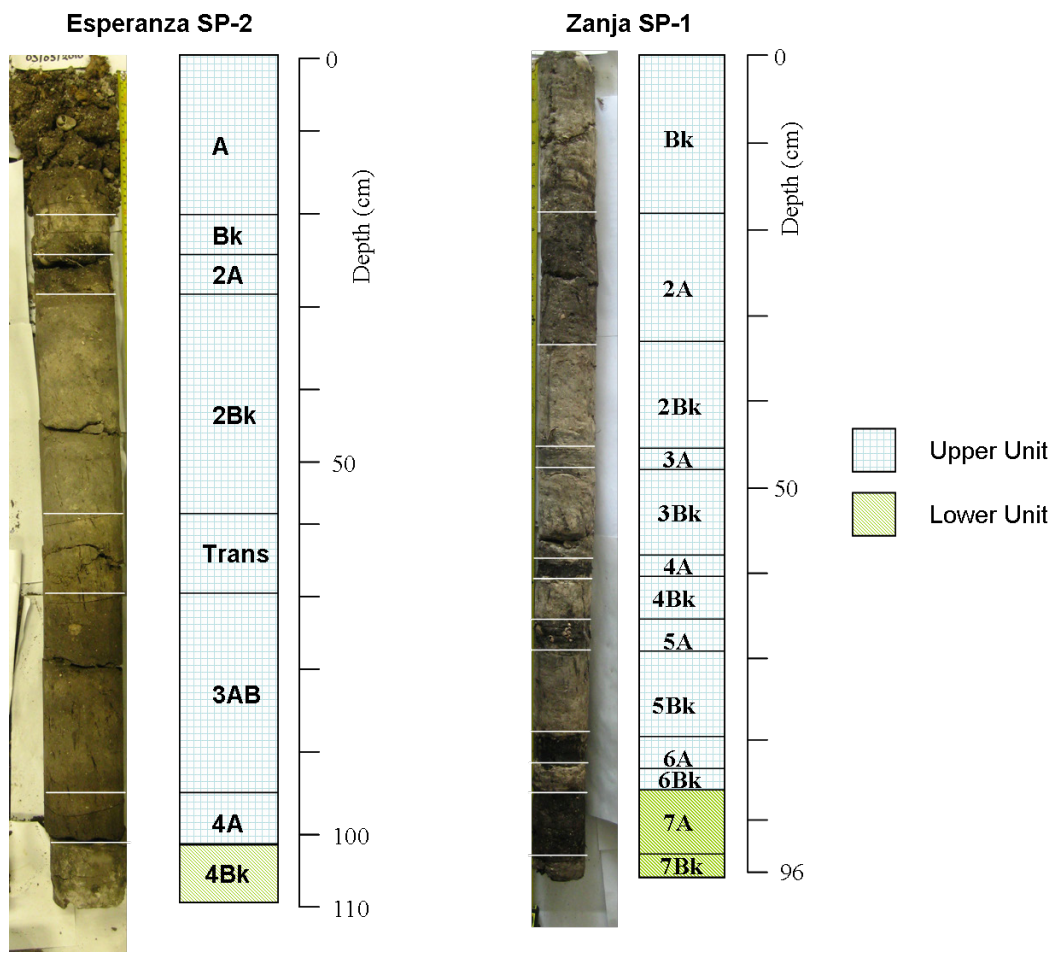

Figure 8 Esperanza SP-2 and Zanja SP-1 showing stratigraphic horizons and separation between upper and lower units. Note: in Esperanza SP-2, the "Trans" horizon stands for "Transition".

occurs similarly in the gleyic horizons $(2 \mathrm{Bg}$ and $2 \mathrm{Btg}$ horizons) seen in the lower unit at Media Luna.

The presence of gypsum is particularly interesting. Gypsum is typically associated with saline groundwater, but in this case, since pyrite was identified elsewhere, it could be that gypsum appeared due to pyrite oxidation and further interaction of sulfuric acid with carbonates. The deep pyrite in Esperanza SP-2 (4Bk horizon) was permanently saturated, and therefore did not oxidize. In shallower horizons (such as Media Luna 2A horizon), pyrite could have been present, oxidized, and all that remains visible now is gypsum.

\subsection{INITIAL INTERPRETATION GORRELATING YALAHAU SETTLEMENT HISTORY, WETLAND MODIFICATION, AND PALEOENVIRONMENTAL SEQUENGES}

As discussed above, the lower soil units reflect a variety of ancient soils, which have been buried by the more recent, and relatively uniform, carbonate-enriched flood-water derived upper units. It should be noted that although only 5 profiles were studied in detail, 25 others show an even greater variety of pedogenic features. Many of these 25 profiles have organic strata beneath carbonate layers, indicating that numerous other wetlands were swampy but unflooded in the past. However, as indicated by the radiocarbon dates (see Figure 7, Table 1), the transitions between the lower and upper units did not occur at the same time. In Esperanza, the transition occurred in the Early Preclassic period (prior to 1460 to $1292 \mathrm{BC}$ ) while in Zanja SP-1 it occurred at the end of the Late Preclassic period (between 205-37 BC and 323-407 AD), and in Media Luna SP-1 it occurred early in the Classic period (after 248-413 AD). Regarding the presence of rock alignments in the studied wetlands and association with the studied cores, Media Luna and Pichol contain far more rock alignments than Zanja and Esperanza (1 and 3 respectively). While no stratigraphic relationship has been established and alignments have not 
Media Luna SP-1

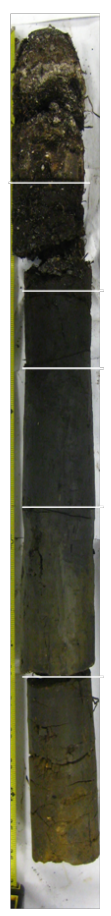

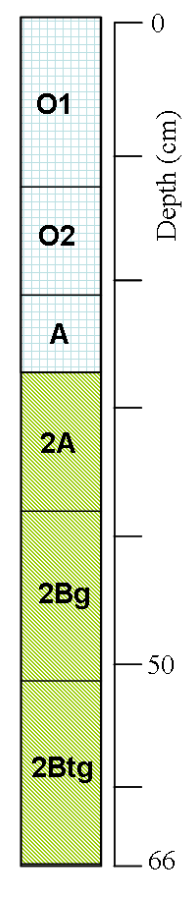

Pichol SP-2

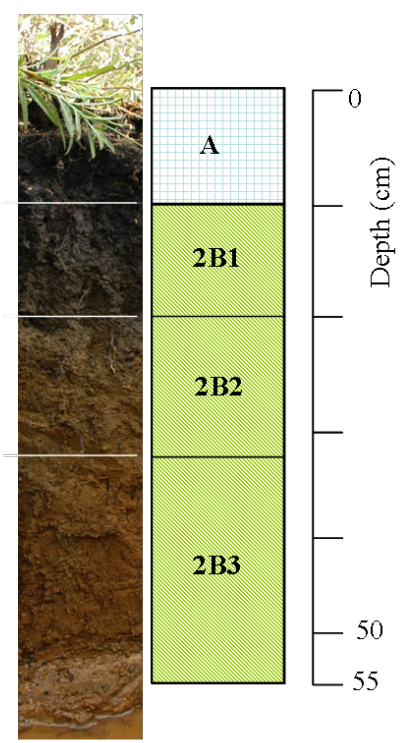

Zanja SP-3

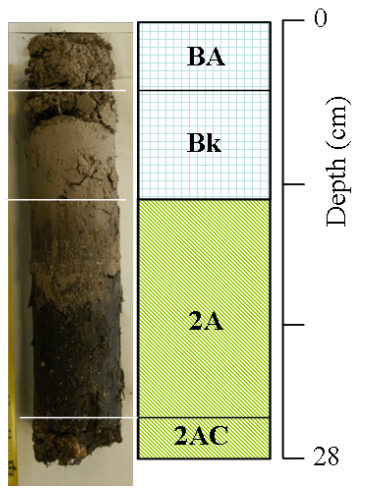

\section{Upper Unit Lower Unit}

Figure 9 Media Luna SP-1, Pichol SP-2, and Zanja SP-2 showing stratigraphic horizons and separation between upper and lower units.

been dated, we suspect that the concentration of alignments at Media Luna and Pichol relates to a later onset of flooding than in wetlands such as Esperanza, where flooding began in the Early Preclassic. In Media Luna and Pichol, cores were extracted in close proximity to rock alignments, and it is supposed that alignments are stratigraphically associated with lower unit soil cover when at least the margins of the wetland rarely flooded, and alignments in lower areas of these wetlands may have been buried by upper unit soils, as flooding increased through the late Holocene and Calcisols developed. In other wetlands not studied here, rock alignments are common at wetlands with lower unit organic strata.

In the context of Maya settlement history and agricultural exploitation of wetlands, it is suggested, as a most likely scenario, that the absence of surface flooding in certain wetlands during the Preclassic period was advantageous to the Yalahau Maya. In the Preclassic period, many wetlands such as Media Luna and Pichol were more like broad, soil-filled depressions that were excellent for farming during the dry season. It is suggested that the Maya constructed the majority of rock alignments during this time, primarily in swampy but unflooded wetlands, to function as low-slope terraces to trap soil (as earlier hypothesized), or to protect young crops from rapid surface runoff into the depressions, near the end of the rainy season (for more on potential cultivation methods, see Fedick et al., 2000:145). These particular wetlands generally did not flood in the Late Preclassic because the water table was perhaps $\sim 1 \mathrm{~m}$ lower 
than it is today (Fedick et al., 2000:143). Swampy, but unflooded, conditions prevailed as evidenced by the lower units observed in the cores.

Subsequently, sometime in the Early Classic, wetlands began to flood more regularly, with algae communities developing and starting to build up calcareous muds. Gradually the number of wetlands suitable for dry season farming dwindled and impacted the regional subsistence system, and gradually the region was abandoned sometime around $\mathrm{AD}$ 400. A similar explanation is given for the Late Preclassic period abandonment of wetland farming at Albion Island in Belize (Pohl et al., 1990).

When Maya people returned to the Yalahau region in the Late Postclassic (AD 1200-1542), there is good evidence from the ancient settlement of T'isil (Fedick et al., 2012) that people took advantage of the more regularly flooded wetland and associated resources. For example, at T'isil (Figure 1), fish bone, turtle shell, and apple snails were recovered from Postclassic deposits, as were fish-net weights made on Postclassic ceramic sherds (Goossens, 2005).

In near-coastal areas around the Yucatán peninsula, numerous studies have documented late Holocene sea rise (Fairbanks, 1989; Lambeck and Chapell, 2001; Toscano and MacIntyre, 2003) and consequent water table rise (Perry et al., 2003). At wetlands in northern Belize, soil-sediment sequences record this water table rise, as well as Maya responses such as canal-digging and raised field construction (Turner and Harrison, 1983; Alcala-Herrera et al., 1994; Pope et al., 1996; Beach et al., 2009). Elsewhere around the Peninsula, sediment cores extracted from lakes have been interpreted to reflect climate changes (Leyden et al., 1996; Brenner et al., 2003; Hodell et al., 2007). For example, at Punta Laguna in the northeastern Yucatan Peninsula (just south of the Yalahau region), alternating bands of organic- and carbonate-enriched strata were interpreted to reflect lower and higher lake stands, suggested to be a product of lesser and greater rainfall (Hodell et al., 2007). Periods of lesser rainfall (droughts) in turn have been linked to Maya sociopolitical reorganization during the Late Preclassic (Carrillo-Bastos et al., 2010; Kennett et al., 2012; Douglas et al., 2015) as well as to the Terminal Classic collapse (Hodell et al., 1995, 2001; Haug et al., 2003; Hodell et al., 2005, 2007; Webster et al., 2007; Medina-Elizalde et al., 2010).

In the Yalahau region, the soil sequences considered in this study provide a record of changing hydrologic conditions and, potentially, a record of anthropogenic manipulation of wetland soilscapes. According to previous soil studies in the region (Solleiro-Rebolledo et al., 2011; Wollwage et al., 2012), wetlands were impacted both by a gradual rise in water table over the last several thousand years, as well as changes in climate including droughts and moist periods. Water table rise may have occurred in starts and stops in accordance with sea rise, as documented by Beddows et al. (2016), independent of rainfall patterns such as droughts and moist periods such as those recorded by Hodell et al. (1995, 2001, 2005, 2007) and many others. Nevertheless, the overall trend has been one of rising sea level, increased flooding and horizontal expansion of wetland areas, and aggradation of wetland soilscapes. In the profiles studied, this is recorded by the transition from lower units to upper units. Unique soil features identified in the lower units of the cores reflect swampy but generally unflooded conditions. Subsequently, increases in flooding and water table level lead to the formation of strata of primarily micritic groundmass - the upper units.

It is in the context of these changing hydrologic conditions and shifts from swampy to more regularly flooded conditions that we must consider the archaeology: specifically, the fact that the Maya constructed hundreds of rock alignments in 20 of 26 wetlands thus far surveyed. It is important to consider that the transition from lower to upper units occurred at different times in different 
a

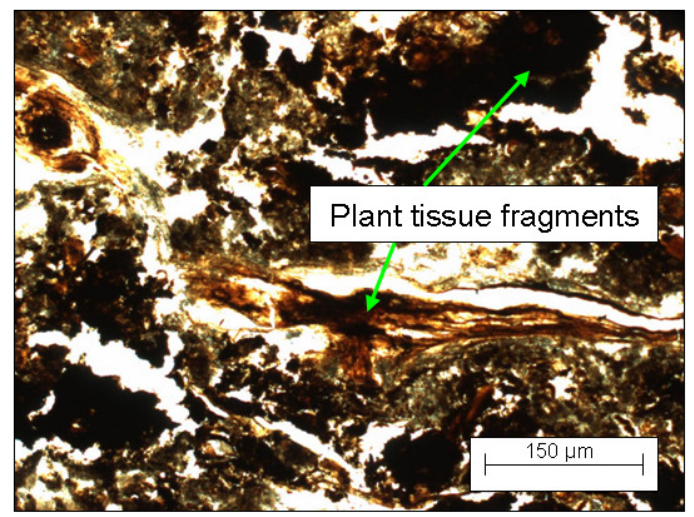

C

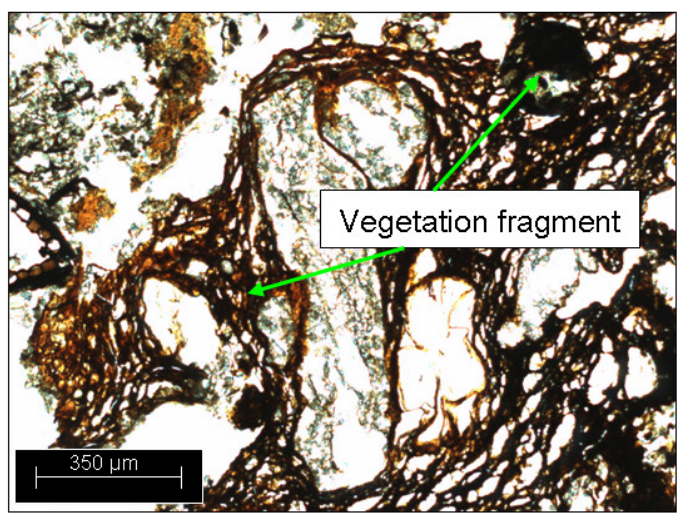

e

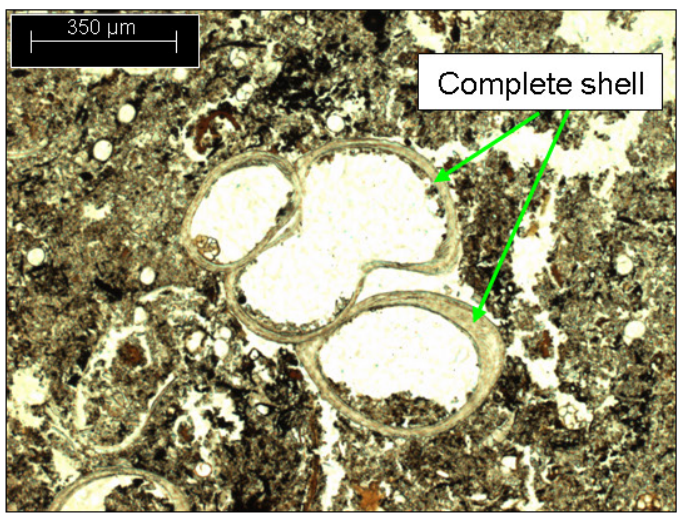

b

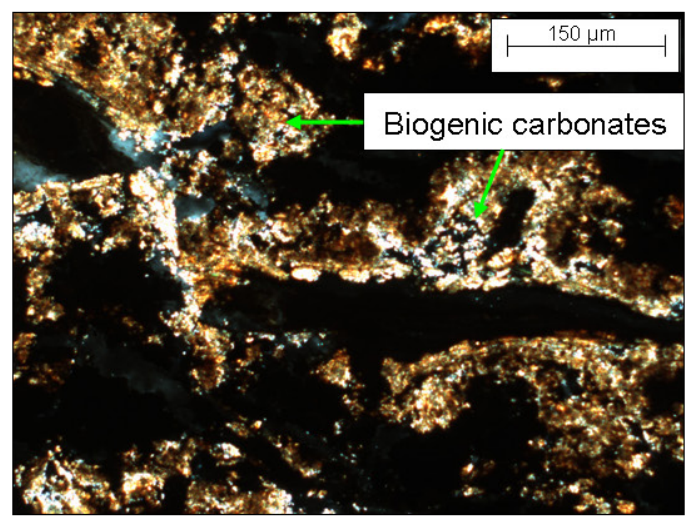

d

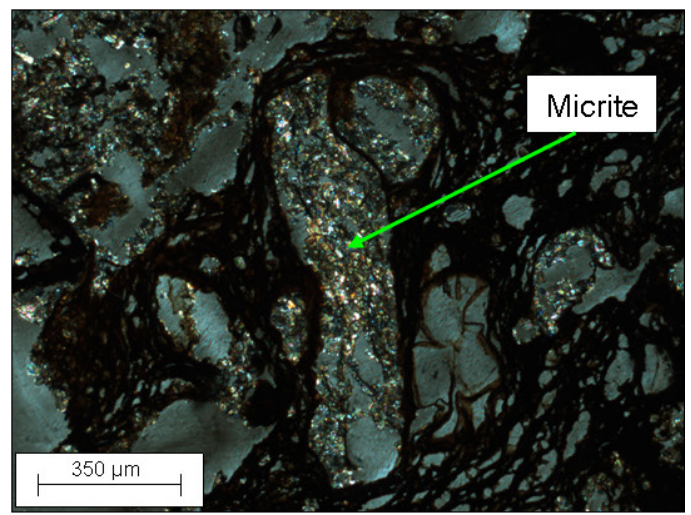

f

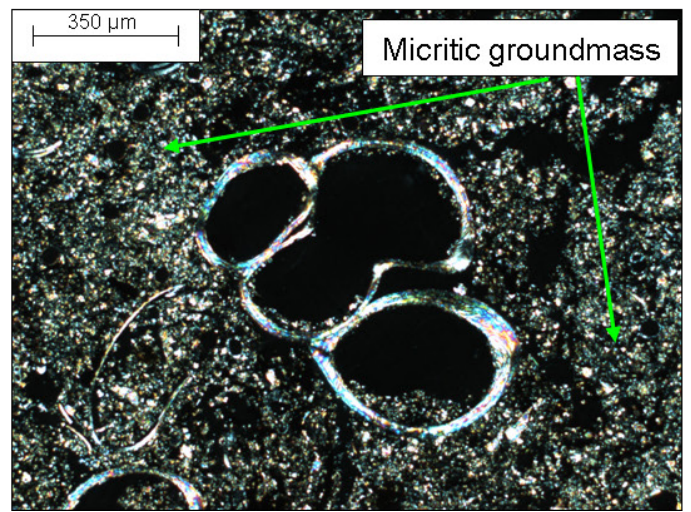

Figure 10 Micromorphology of upper unit soils. PPL - plane polarized light, XPL - crossed polarizers, RF - reflected light. (a) Zanja SP-1, 6A horizon: organic matter in the form of partly decomposed fragments of plant tissues, PPL. (b) Same as (a), XPL; note strong interference colors of biogenic carbonates, precipitated over plant fragments. (c) Media Luna SP-1, O1-O2 horizon: large intact vegetation fragment, PPL. (d) Same as (c), XPL; note micrite infillings in some pores of the vegetation fragment. (e) Zanja SP-1, the 3Bk horizon shows a complete shell, in a micritic groundmass locally containing dark organic pigment, PPL. (f) Same as (e), XPL. 
a

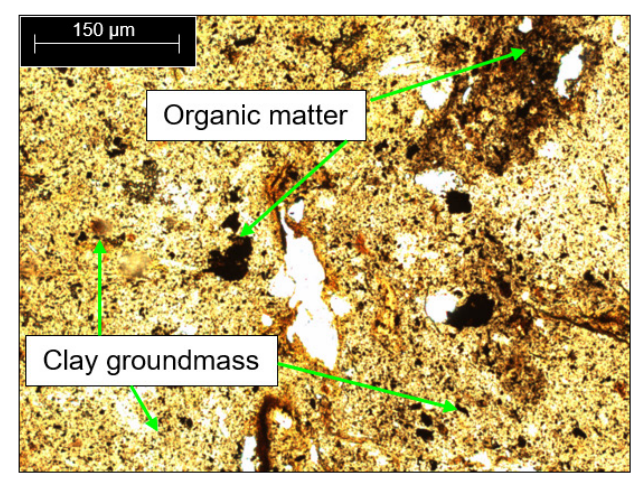

C

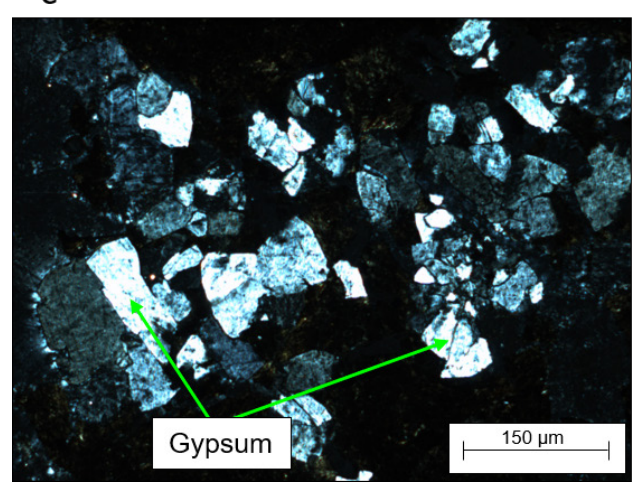

b

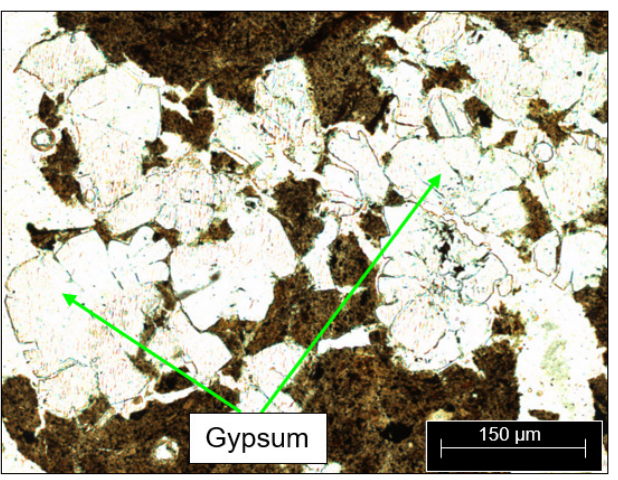

d

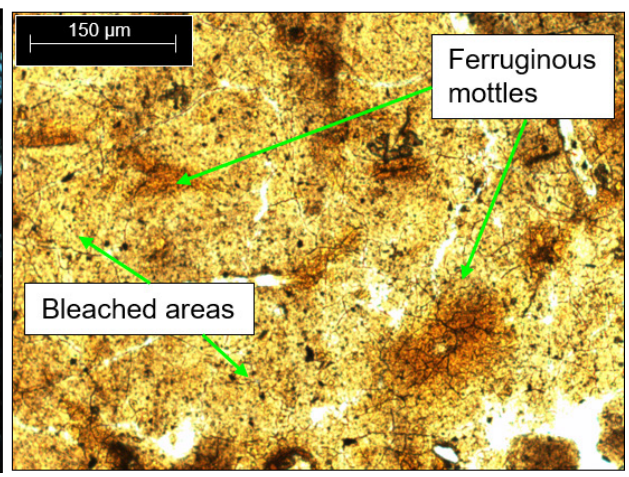

Figure 11 Micromorphology of lower unit soils. (a) Media Luna SP-1, 2A horizon: overview of the groundmass showing clay locally containing organic pigment, PPL. (b) Media Luna SP-1: gypsum infilling in the 2A horizon surrounded by clay-humus groundmass, PPL. (c) Same as (b), XPL. (d) Media Luna SP-1, 2Btg horizon: clay groundmass with bleached areas alternating with ferruginous mottles, PPL.

wetlands, probably dependent on individual wetland elevation and surrounding topography. This is evident from the radiocarbon dates. For example, in the Esperanza wetland, the transition from swampy conditions to regular annual flooding appears to have occurred very early on (prior to 1460 to $1292 \mathrm{BC}$ ), long before we have evidence of settlement in the region. This does not mean that it was not used by the Maya as a resource of the subsistence economy. However, the paucity of rock alignments (only 3) suggests it was not suitable for manipulation with rock alignments, or that rock alignments were not needed. In Zanja SP-1 the transition occurred at the end of the Late Preclassic period (between 205-37 BC and 323-407
AD), and in Media Luna SP-1 it occurred early in the Classic period (after 248-413 AD).

\section{Conclusions}

The research presented in this study helps to visualize wetland landscapes of the Yalahau region and how these landscapes changed over three millennia of Maya occupation. The findings demonstrate that the wetland ecosystems of today; soils, biota, and hydrology, are very different than those encountered by the earliest Maya settlers. The findings, while preliminary in nature, also suggest that a significant regional change in 
wetland flooding regimes occurred, with lower soil units representing a lower water table and variable degrees of saturation or flooding, and upper soil units representing a higher water table and more uniform flooding.

The micromorphological observations of the study cores of the Yalahau region were used to identify the various types of pedogenetic features and to distinguish two units: an upper unit dominated by biogenic micrite, and a lower unit characterized by a variety of unique soil features such as sparitic calcite crystals, pyrite, gypsum, and gleyic properties. Based on these observations, it is suggested that modern soil forming processes are fairly uniform a

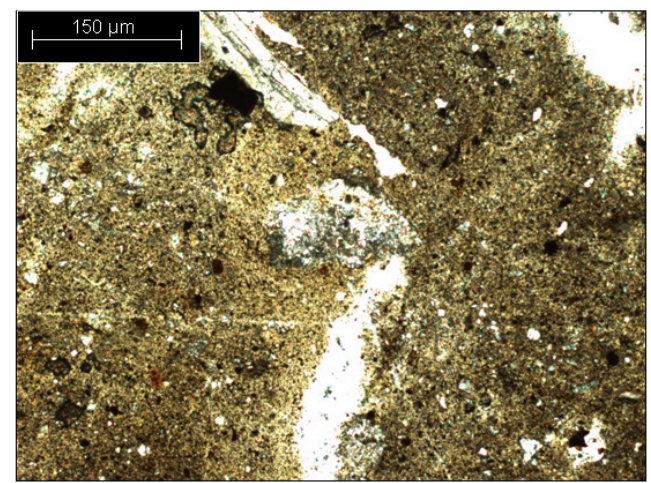

C

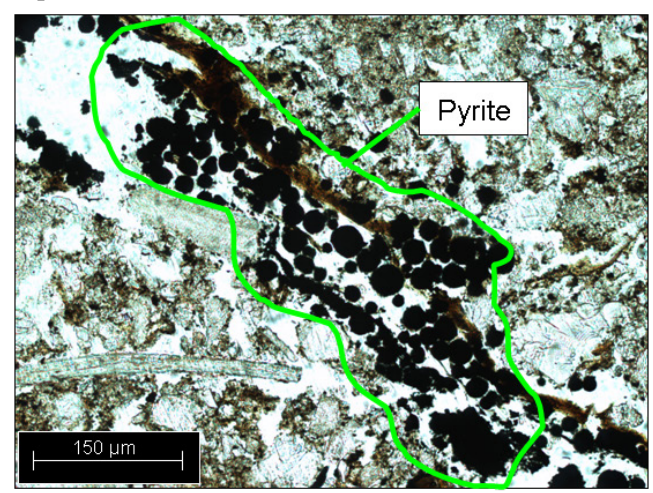

e

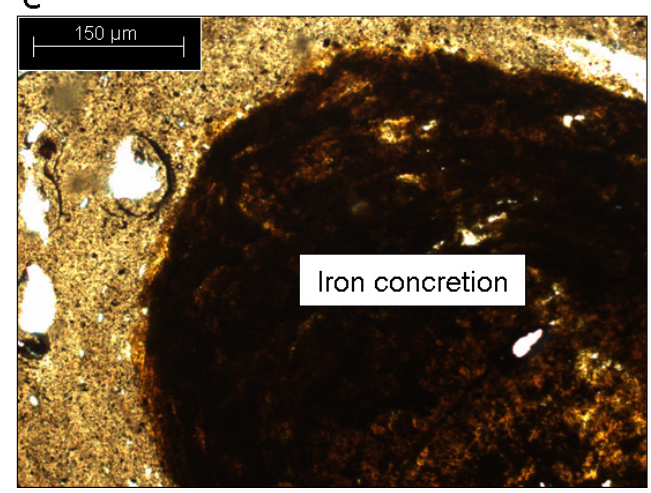

b

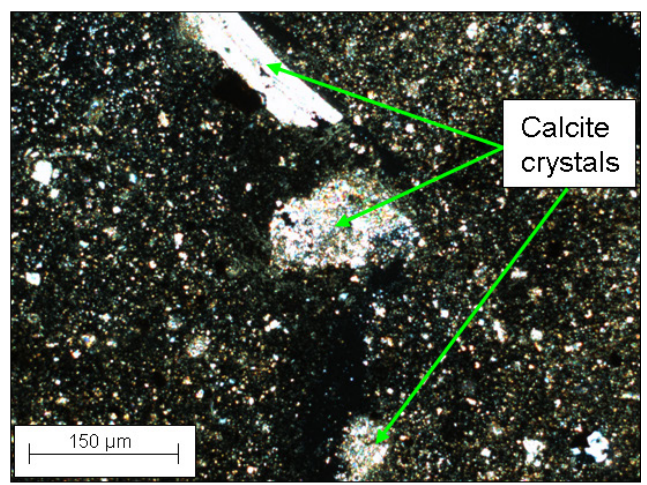

d

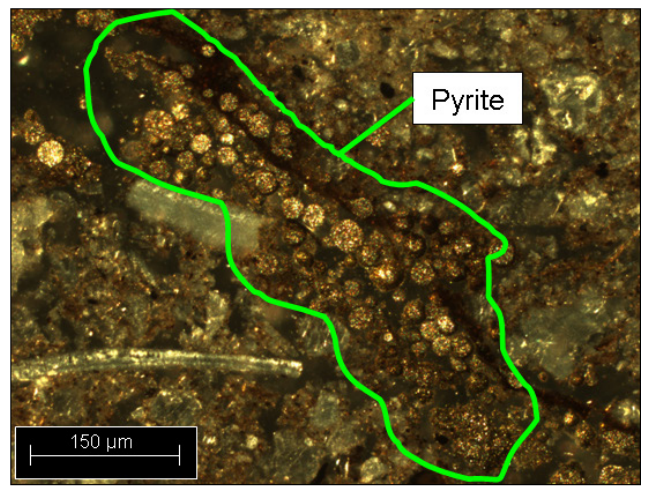

$f$

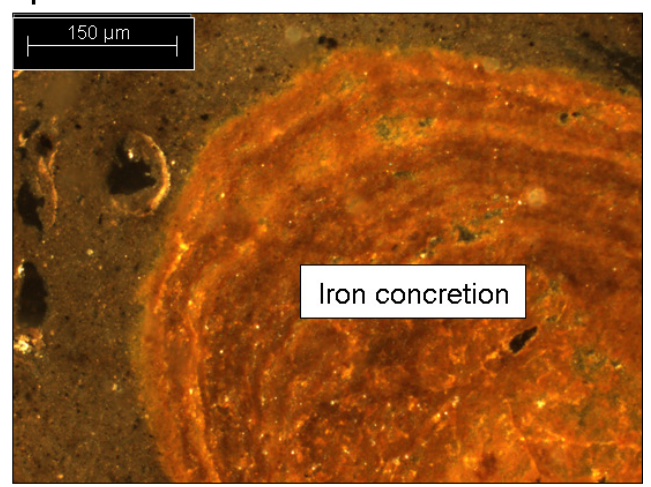

Figure 12 Micromorphology of lower unit soils. (a) Zanja SP-3, 2A horizon: groundmass consisting of micrite, sparite and collomorphic organic material, PPL. (b) Same as (a), XPL; note strong interference colors of a few large calcite crystals. (c) Esperanza SP-2, pyrite in the 4Bk horizon, PPL. (d) Same as (c), RF. (e) Pichol SP-2, 2B horizon showing an iron concretion, PPL. (f) Same as (e), RF; note concentric structure of the concretion. 
across the region and controlled by regular annual flooding ( $\sim 7$ months of $>1 \mathrm{~m}$ deep flooding each year), while in the past (Preclassic period), flooding was less regular and wetland environments were more swampy and varied.

It is suggested that the Preclassic depressions encountered by the Maya were a prime agricultural resource that allowed the region to flourish during the Late Preclassic period when the regional population level peaked (Fedick and Mathews, 2005; Rissolo et al., 2005; Glover and Stanton, 2010; Glover, 2012). During this time, as shown by the radiocarbon dated soil sequences studied here, it is evident that at least some wetlands such as Media Luna, were swampy but unflooded. Media Luna and Pichol (with a similar profile to Media Luna) are wetlands with some of the highest concentrations of rock alignments. It is suggested that the concentration of alignments at Media Luna and Pichol relates to a later onset of flooding than in wetlands such as Esperanza, where flooding began in the Early Preclassic. In Media Luna and Pichol, cores were extracted in close proximity to rock alignments, and it is further suspected that alignments are stratigraphically associated with lower unit soil cover when at least the margins of the wetland rarely flooded. In other wetlands that were surveyed and cored, but not studied here, rock alignments are common at wetlands with lower unit organic strata (similar to Media Luna and Pichol).

Future soils research should continue investigating the diversity of soil resources that exist throughout the region, specifically focusing on the development of well-dated paleoenvironmental reconstructions of changing wetland flood conditions in many more wetlands. In particular, additional dates are needed from Media Luna to better anchor the chronological framework of that site. Future investigations should also examine how variable hydrological histories of individual wetlands may be influenced by localized topography and drainage patterns, in addition to regional water table fluctuations resulting from sea level change. It may also be possible to better define the distribution of rock alignments in relation to wetlands with varying hydrological histories, and to identify and date the stratigraphic position of rock alignments.

\section{Acknowledgements}

We would like to thank the Instituto Nacional de Antropología e Historia (INAH) and the Consejo de Arqueología de INAH for granting permission to conduct archaeological research in Quintana Roo. Thanks to the Yalahau Project and the UCR Center for Conservation Biology for logistical support. Thanks to Charles Bush for enthusiasm, hospitality, and support of the Yalahau project. We are grateful to the ejidos of the Yalahau region for permission to visit their lands, and to local Maya guides, especially Pepe Quintal, Don Jose Mex Yann, and Gustavo Tuz Ramirez for their hard work in the wetlands and their assistance with local contacts and area history. Thanks to those students who assisted with field data collection, especially Jennifer Chmilar, Jeffrey Vadala, Lucia Gudiel, John Gust, and Samanta Jaime. Also, thanks to Rene Alcala and our colleagues at UNAM for assistance with sample processing. Generous funds for this research were provided by grants from PAPIIT IN103617 - Coevolución de la cubierta edáfica en los geo-sistemas kársticos de Yucatán: un enfoque integral, the National Science Foundation, UC-MEXUS, UC-MEXUS/ CONACYT, and the UGR Graduate Division. Finally, thank you to the reviewers for comments and suggestions that have helped to improve this article. 


\section{References}

Alcala-Herrera, J.A., Jacob, J.S., MachainCastillo, M.L., Neck, R.W., 1994, Holocene paleosalinity in a Maya wetland, Belize, inferred from the microfaunal assemblage: Quaternary Research, 41(1), 121-130.

Andersen, B.J., 2001, Pre-Hispanic subsistence strategies: A comparison between $\mathrm{El}$ Edén and other selected sites in the Maya Lowlands: Copenhagen, Denmark, Institute for Archaeology and Ethnography, University of Denmark, Master's thesis, 115 p.

Anselmetti, F.S., Hodell, D.A, Ariztegui, D., Brenner, M., Rosenmeier, M.F., 2007, Quantification of soil erosion rates related to ancient Maya deforestation: Geology, 35(10), 915-918.

Beach, T., Dunning, N., Luzzadder-Beach, S., Cook, D., Lohse, J., 2006, Impacts of the ancient Maya on soils and soil erosion in the central Maya Lowlands: Catena, 65(2), 166-178.

Beach, T., Luzzadder-Beach, S., Dunning, N., Jones, J., Lohse, J., Guderjan, T., Bozarth, S., Millspaugh, S., Bhattacharya, T., 2009, A Review of human and natural changes in Maya Lowland wetlands over the Holocene: Quaternary Science Reviews, 28(17-18), 1710-1724.

Beach, T., Luzzadder-Beach, S., Cook, D., Dunning, N., Kennett, D.J., Krause, S., Terry, R., Trein, D., Valdez, F., 2015, Ancient Maya impacts on the Earth's surface: An early Anthropocene analog?: Quaternary Science Reviews, 124, 1-30.

Beddows, P.A., Glover, J.B. Rissolo, D., Carter, A.M., Jaijel, R., Smith, D.M., GoodmanTchernov, B., 2016, The Proyecto Costa Escondida: Recent interdisciplinary research in search of freshwater along the north coast of Quintana Roo, Mexico: Wiley Interdisciplinary Reviews: Water, 3(5), 749-761.

Bell, J.A., 1998, A developing model for determining cenote and associated site settlement patterns in the Yalahau region, Quintana Roo, Mexico: Riverside, U.S.A, University of California, Riverside, Master's thesis, $86 \mathrm{p}$.

Berry, K.A., McAnany, P.A., 2007, Reckoning with the wetlands and their role in ancient Maya society, in Scarborough, V.L., Clark, J.E. (eds.), The political economy of ancient Mesoamerica: Transformations during the Formative and Classic periods: Albuquerque, U.S.A., University of New Mexico Press, 149-162.

Bey, G.J. III, Bond, T.M., Ringle, W.M., Hanson, C.A., Houck, C.W., Peraza-Lope, C.P., 1998, The ceramic chronology of Ek Balam, Yucatán, Mexico: Ancient Mesoamerica, 9(1), 101-120.

Brenner, M., Hodell, D.A., Curtis, J.H., Rosenmeier, M.F., Anselmetti, F.S., Ariztegui, D., 2003, Paleolimnological approaches for inferring past climate change in the Maya region: Recent advances and methodological limitations, in Gómez-Pompa, A., Allen, M.F., Fedick, S.L., Jiménez-Osornio, J.J (eds.), The lowland Maya area: Three millennia at the human-wildland interface: Binghamton, U.S.A., Hawthorn Press, 45-75.

Carrillo-Bastos, A., Islebe, G.A., TorrescanoValle, N., González, N.E., 2010, Holocene vegetation and climate history of central Quintana Roo, Yucatán Península, Mexico: Review of Palaeobotany and Palynology, 160(3-3), 189-196.

Charvet, G., 2009, Exploration, modeling and management of groundwater resources in northern Quintana Roo, Mexico: Kongens 
Lyngby, Denmark, Technical University of Denmark, Department of Environmental Engineering, Master's thesis, 123 p.

Chmilar, J.A., 2013, Ancient Maya cultivation in a dynamic wetland environment: Insights into the functions of anthropogenic rock alignments at El Edén Ecological Reserve, Quintana Roo, Mexico: Riverside, U.S.A, University of California, Riverside, $\mathrm{PhD}$ dissertation, $230 \mathrm{p}$.

Comisión Nacional del Agua, 2008, Comisión Nacional del Agua, Servicio Meteorológico Nacional, Climate data for the Kantunilkin, Quintana Roo station (on line): Mexico City, Mexico, available in <http://smn. cna.gob. $\mathrm{mx} /$ index.php?option $=\mathrm{com}_{-}$ content $\&$ view $=$ article $\& i d=42 \&$ Itemid $=28>$, accessed July 11, 2012.

Curtis, J.H., Brenner, M., Hodell, D.A., Balser, R.A., Islebe, G.A., Hooghiemstra, H., 1998, A multi-proxy study of Holocene environmental change in the Maya Lowlands of Peten, Guatemala: Journal of Paleolimnology, 19(2), 139-159.

Douglas, P.M.J., Pagani, M., Canuto, M.A., Brenner, M., Hodell, D.A., Eglinton, T.I., Curtis, J.H., 2015, Drought, agricultural adaptation, and sociopolitical collapse in the Maya Lowlands: Proceedings of the National Academy of Sciences of the United States of America, 112(18), 5607-5612.

Dunning, N.P., Beach, T., Luzadder-Beach, S., 2006, Environmental variability among bajos in the southern Maya Lowlands and its implications for ancient Maya civilization and archaeology, in Lucero, L.J., Fash, B.W. (eds.), Precolumbian water management: Ideology, ritual, and power: Tucson, U.S.A., University of Arizona Press, 81-99.

Dunning, N.P., McCane, C., Swinney, T., Purtill, P., Sparks, J., Mann, A., McCool, J.P., Ivenso, C., 2015, Geoarchaeological investigations in
Mesoamerica move into the 21st century: A review: Geoarchaeology, 30(3), 167-199.

Durand, N., Monger, H.G., Canti, M.G., 2010, Calcium carbonate features, in Stoops, G., Marcelino, V., Mees, F. (eds.), Interpretation of Micromorphological Features of Soils and Regoliths: Amsterdam, The Netherlands, Elsevier, 149-194.

Fairbanks, R.G., 1989, A 17,000-year glacioeustatic sea level record: Influence of glacial melting rates on the Younger Dryas event and deep-ocean circulation: Nature, 342, 637-642.

Fedick, S.L. (ed.), 1998a, El proyecto Yalahau: Informe técnico final sobre las investigaciones arqueológicas de 1996-1997 en el norte de Quintana Roo, México: Mexico City, Mexico, report prepared for the Consejo de Arqueología del Instituto Nacional de Antropología e Historia, 251 p.

Fedick, S.L., 1998b, Ancient Maya use of wetlands in northern Quintana Roo, Mexico, in Bernick, K. (ed.), Hidden Dimensions: The Cultural Significance of Wetland Archaeology: Vancouver, Canada, UBC Press, 107-129.

Fedick, S.L., 2014, A reassessment of water and soil resources in the flatlands of the northern Maya Lowlands: Archeological Papers of the American Anthropological Association, 24(1), 72-83.

Fedick, S.L., Taube, K.A. (eds.), 1995, The view from Yalahau: 1993 archaeological investigations in northern Quintana Roo, Mexico: Riverside, U.S.A., University of California, Riverside, $151 \mathrm{p}$.

Fedick, S.L., Mathews, J.P., 2005, The Yaluhau regional human ecology project: An introduction and summary of recent research, in Shaw, J., Mathews, J. (eds.), Quintana Roo Archaeology: Tucson, U.S.A., The University of Arizona Press, 33-50. 
Fedick, S.L., Morrison, B.A., Andersen, B.J., Boucher, S., Acosta, J.C., Mathews, J.P., 2000, Wetland manipulation in the Yalahau region of the northern Maya Lowlands: Journal of Field Archaeology, 27(2), 131-152.

Fedick, S.L., Mathews, J.P., Sorensen, K., 2012, Cenotes as conceptual boundary markers at the ancient Maya site of T'isil, Quintana Roo, Mexico: Mexicon, 34(5), 118-123.

Folan, W.J., Anaya-Hernandez, A., Kintz, E.R., Fletcher, L.A., Gonzalez-Heredia, R., May-Hau, J., Caamal-Canche, N., 2009, Coba, Quintana Roo, Mexico: A recent analysis of the social, economic and political organization of a major Maya urban center: Ancient Mesoamerica, 20(1), 59-70.

Folan, W.J., Kintz, E.R., Fletcher, L.A., 1983, Cobá: A Classic Maya metropolis: New York, U.S.A., Academic Press, 253 p.

Gliessman, S. R., Turner, B.L.II, Rosado-May, F.J., Amador, M.F., 1983, Ancient raised field agriculture in the Maya Lowlands of southeastern Mexico, in Darch, J.P. (ed.), Drained field agriculture in Central and South America: Oxford, England, BAR International Series 189, British Archaeological Reports, 91-110.

Glover, J.B., 2006, The Yalahau regional settlement pattern survey: A study of ancient Maya social organization in northern Quintana Roo, Mexico: Riverside, U.S.A, University of California, Riverside, $\mathrm{PhD}$ dissertation, 853 p.

Glover, J.B., 2012, The Yalahau region: A study of ancient Maya socio-political organization: Ancient Mesoamerica, 23(2), 271-295.

Glover, J.B., Stanton, T.W., 2010, Assessing the role of Preclassic traditions in the formation of Early Classic Yucatec cultures, Mexico: Journal of Field Archaeology, 35(1), 58-77.

Gondwe, B.R.N., Auken, E., Bauer-Gottwein, P., 2010, Exploration, modelling and management of groundwater-dependent ecosystems in karst - the Sian Ka'an case study, Yucatan, Mexico: Lyngby, Denmark, Technical University of Denmark, PhD dissertation, $86 \mathrm{p}$.

Goossens, M., 2005, Faunal analysis from the ancient Maya site of T'isil in Quintana Roo, Mexico: Fullerton, U.S.A., California State University, Master's thesis, 104 p.

Gust, J., 2016, Bittersweet: Porfirian sugar and rum production in northeastern Yucatán: Riverside, U.S.A., University of California, Riverside, Ph.D. dissertation, 510 p.

Hammond, N., Donaghey, S., Gleason, C., Staneko, J.C., Van Tuerenhout, D., Kosakowsky, L.J., 1987, Excavations at Nohmul, Belize, 1985: Journal of Field Archaeology, 14(3), 257-281.

Hansen, R.D., Bozarth, S., Jacob, J., Wahl, W., Schreiner, T., 2002, Climatic and environmental variability in the rise of Maya civilization: a preliminary perspective from northern Peten: Ancient Mesoamerica, 13(2), 273-295.

Haug, G.H., Günther, D., Peterson, L.C., Sigman, D.M., Hughen, K.A., Aeschlimann, B., 2003, Glimate and the collpase of Maya civilization: Science, 299, 1731-1735.

Hixon, D. R., 2011, Settlement Patterns and Communication Routes of the Western Maya Wetlands: An Archaeological and Remote Sensing Survey, Chunchucmil, Yucatan, Mexico: New Orleans, U.S.A., Tulane University, PhD dissertation, 435 p.

Hodell, D.A., Curtis, J.H., Brenner, M., 1995, Possible role of climate in the collapse of classic Maya civilization: Nature, 375, 391-394.

Hodell, D.A., Brenner, M., Curtis, J.H., Guilderson, T., 2001, Solar forcing of drought frequency in the Maya Lowlands: Science, 292, 1367-1370.

Hodell, D.A., Brenner, M., Curtis, J., 2005, Terminal Classic drought in the northern Maya Lowlands inferred from multiple 
sediment cores in Lake Chichancanab (Mexico): Quaternary Science Reviews, 24(12-13), 1413-1427.

Hodell, D.A., Brenner, M., Curtis, J.H., 2007, Climate and culture history of the northeastern Yucatan Peninsula, Quintana Roo, Mexico: Climate Change, 83(1-2), 215-240.

IUSS Working Group WRB, 2015, World Reference Base for Soil Resources 2014, update 2015 International soil classification system for naming soils and creating legends for soil maps: Rome, Italy, Food and Agriculture Organization of the United Nations, World Soil Resources Reports, 106.

Jacob, S., 1995, Ancient Maya wetland agricultural fields in Cobweb Swamp, Belize: Construction, chronology, and function: Journal of Field Archaeology, 22(2), 175-190.

Kennett, D.J., Breitenbach, S.F.M., Aquino, V.V., Asmerom, Y., Awe, J., Baldini, J.U.L., Bartlein, P., Culleton, B.J., Ebert, C., Jazwa, C., Macri, M.J., Marwan, N., Polyak, V., Prufer, K.M., Ridley, H.E., Sodemann, H., Winterhalder, B., Haug, G.H, 2012, Development and disintegration of Maya political systems in response to climate change: Science, 338(6108), 788-791.

Kepecs, S., 1998, Diachronic ceramic evidence and its social implications in the Chikinchel region, northeast Yucatan, Mexico: Ancient Mesoamerica, 9(1), 121-136.

Lambeck, K., Chappell, J, 2001, Sea level change through the last glacial cycle: Science, 292(5517), 679-686.

Lambert, J.D.H., Siemens, A.H., Arnason, J.T., 1984, Ancient Maya drained field agriculture: Its possible application in the New River floodplain, Belize, C.A: Agriculture, Ecosystems \& Environment, 11(1), 67-84.

Lauderdale, R.W., Ward, W.C., Weidie, A.E., 1979, "Carillo Puerto Formation" of northeastern Quintana Roo, Mexico: Gul Coast Association of Geological Societies Transactions, 29, 275-280.

Leonard, D.I., 2013, The Yalahau regional wetland survey: Ancient Maya land use in northern Quintana Roo, Mexico: Riverside, U.S.A, University of California, Riverside, $\mathrm{PhD}$ dissertation, $668 \mathrm{p}$.

Leyden, B. W., Brenner, M., Whitmore, T., Curtis, J. H., Piperno, D. R., Dahlin, B. H., 1996, A Record of Long- and Short-Term Climatic Variation from the Northwest Yucatan: Cenote San Jose Chulchaca, in Fedick, S.L. (ed.), The Managed Mosaic: Ancient Maya Agriculture and Resource Use: Salt Lake City, U.S.A., University of Utah Press, 30-50.

Lugo-Hubp J., Aceves-Quesada J., EspinasaPereña R., 1992, Rasgos geomorfológicos mayores de la península de Yucatán: Revista del Instituto de Geología, 10(2): 143-150.

Mathews, J.P., 1998, The ties that bind: The ancient Maya interaction spheres of the Late Preclassic and Early Classic Periods in the northern Yucatán Peninsula: Riverside, U.S.A., University of California, Riverside, $\mathrm{PhD}$ dissertation, $470 \mathrm{p}$.

Medina-Elizalde, M., Burns, S.J., Lea, D.W., Asmerom, Y., von Gunten, L., Polyak, V., Vuille, M., Karmalkar, A., 2010, High resolution stalagmite climate record from the Yucatán Peninsula spanning the Maya terminal classic period: Earth and Planetary Science Letters, 298(1-2), 255-262.

Miedema, R., Jongmans, A.G., Slager, S, 1974, Micromorphological observation on pyrite and its oxidation products in four Holocene alluvial soils in The Netherlands, in Rutherford, G.K. (ed.), Soil Microscopy: Kingston, Canada, Limestone Press, 772-794.

Morrison, B., 2000, Ancient Maya settlement of the Yalahau region: An example from the El 
Edén wetland: Riverside, U.S.A., University of California, Riverside, $\mathrm{PhD}$ dissertation, $210 \mathrm{p}$.

Perry, E., Velazquez-Oliman, G., Socki, R.A., 2003, Hydrogeology of the Yucatan Peninsula, in Gómez-Pompa, A., Allen, M.F., Fedick, S.L., Jiménez-Osornio, J.J. (eds.), The lowland Maya area: Three millennia at the human-wildland interface: Binghamton, U.S.A., Hawthorn Press, 115-138.

Poch, R.M., Artieda, O., Herrero, J., LebedevaVerba, M. 2010, Gypsic features, in Stoops, G., Marcelino, V., Mees, F. (eds.), Interpretation of Micromorphological Features of Soils and Regoliths: Amsterdam, The Netherlands, Elsevier, 195-216.

Pohl, M.D. (ed.), 1990, Ancient Maya wetland agriculture: Excavations on Albion Island, northern Belize: Boulder, U.S.A., Westview Press, 439 p.

Pohl, M.D, Bloom, P.R., Pope, K.O., 1990, Interpretation of wetland farming in northern Belize: Excavations at San Antonio Rio Hondo, in Pohl, M.D. (ed.), Ancient Maya wetland agriculture: Excavations on Albion Island, Northern Belize: Boulder, U.S.A., Westview Press, 187-254.

Pope, K.O., Pohl, M.D., Jacob, J., 1996, Formation of ancient Maya wetland fields: Natural and anthropogenic processes, in Fedick, S.L. (ed.), The managed mosaic: Ancient Maya agriculture and resource use: Salt Lake City, U.S.A., University of Utah Press, 165-176.

Purdy, E.G., Gischler, E., Lomando, A.J., 2003, The Belize margin revisited. 2. Origin of Holocene antecedent topography: International Journal of Earth Science, 92(4), 552-572.

Rebolledo-Vieyra, M., Urrutia-Fucugauchi, J., Marín, L.E., Trejo-García, A., Sharpton, V.L., Soler-Archalde, A.M., 2000, UNAM scientific shallow-drilling program of the Chicxulub impact crater: International Geology Review, 42(10), 928-940.

Rissolo, D.A., 2001, Ancient Maya cave use in the Yalahau region, northern Quintana Roo, Mexico: Riverside, U.S.A., University of California, Riverside, Ph.D. dissertation, 800 p.

Rissolo, D., Mathews, J.P., 2006, Archaeologists working with the contemporary Yucatec Maya, in Mathews, J.P., Morrison, B.A. (eds.), Lifeways in the northern Maya Lowlands: New approaches to archaeology in the Yucatán Peninsula: Tucson, U.S.A., University of Arizona Press, 198-209.

Rissolo, D., Ochoa Rodriguez, J.M., Ball, J.W., 2005, A reassessment of the Middle Preclassic in northern Quintana Roo, in Shaw, J., Mathews, J. (eds.), Quintana Roo archaeology: Tucson, U.S.A., University of Arizona Press, 66-76.

Robles-Castellanos, F., 1990, La Secuencia Cerámica de la Region de Cobá, Quintana Roo: Mexico City, Mexico, Serie Arqueología, Instituto Nacional de Antropología e Historia, 184, 278 p.

Schultz, G.P., 2003, Structure and diversity of the forests at the El Edén Ecological Reserve, in Gómez-Pompa, A., Allen, M.F., Fedick, S.L., Jiménez-Osornio, J.J (ed.), The lowland Maya area: Three millennia at the humanwildland interface: Binghamton, U.S.A., Hawthorn Press, 91-114.

Servicio Geológico Mexicano (SGM), 2007, Carta geológica de México, scale 1:2,000,000: Pachuca, Mexico, Servicio Geológico Mexicano.

Sedov, S., Solleiro-Rebolledo, E., Fedick, S.L., Gama-Castro, J., Palacios-Mayorga, S.,Vallejo-Gómez, E., 2007, Soil genesis in relation to landscape evolution and ancient 
sustainable land use in the northeastern Yucatan Peninsula, Mexico: Atti della Società Toscana di Scienze naturali, Memorie, Serie A, 112, 115-126.

Sedov, S., Solleiro-Rebolledo, E., Fedick, S.L., Pi-Puig, T., Vallejo-Gómez, E., FloresDelgadillo, M.L., 2008, Micromorphology of a soil catena in Yucatan: Pedogenesis and geomorphological processes in a tropical karst landscape, in Kapur, S., Mermut, A., Stoops, G. (eds.), New trends in micromorphology: Berlin, Germany, Springer-Verlag, 19-37.

Siemens, A.H., Puleston, D.E., 1972, Ridged fields and associated features in southern Campeche: New perspectives on the lowland Maya: American Antiquity, 37(2), 228-239.

Solleiro-Rebolledo, E., Cabadas-Báez, H.V., Pi P.T., González, A., Fedick, S.L., Chmilar, J.A., Leonard, D., 2011, Genesis of hydromorphic Calcisols in wetlands of the northeast Yucatan Peninsula, Mexico: Geomorphology, 135(34), 322-331.

Sorensen, K., 2010, Community organization at the ancient Maya settlement of T'isil, Quintana Roo, Mexico: Riverside, U.S.A., University of California, Riverside, Ph.D. dissertation, $557 \mathrm{p}$.

Stuiver, M., Reimer, P.J., Reimer, R.W., 2013, CABLIB 6.0 Radiocarbon Calibration: Belfast, U.K., Queen's University Belfast, available in <http://calib.qub.ac.uk/ calib/>, accessed July 25, 2013.

Toscano, M.A., MacIntyre, I.G., 2003, Corrected western Atlantic sea-level curve for the last 11,000 years based on calibrated ${ }^{14} \mathrm{C}$ dates from Acropora palmata framework and intertidal mangrove peat: Coral Reefs, 22(3), 257-270.
Tulaczyk, S.M., 1993, Karst geomorphology and hydrogeology of the northeastern Yucatan Peninsula, Mexico: Dekalb, U.S.A., Northern Illinois University, Master's thesis, 189 p.

Turner, B.L.II, Harrison, P.D. (eds.), 1983, Pulltrouser Swamp: Ancient Maya habitat, agriculture, and settlement in northern Belize: Austin, U.S.A., University of Texas Press, $310 \mathrm{p}$.

Webster, J.W., Brook, G.A., Railsback, L.B., Cheng, H., Edwards, R.L., Alexander, C., Reeder, P.P., 2007, Stalagmite evidence from Belize indicating significant droughts at the time of Preclassic abandonment, the Maya hiatus, and the Classic Maya collapse: Palaeogeography, Palaeoclimatology, Palaeoecology, 250(1-4), 1-17.

Weidie, A.E., 1985, Geology of the Yucatan Platform, in Ward, W.G., Weidie, A.E., Back, W. (eds.), Geology and hydrogeology of the Yucatan and Quaternary geology of the northeastern Yucatan Peninsula: New Orleans, U.S.A., New Orleans Geological Society, 1-12.

Wollwage, L.K., 2008, Looking into murky waters, a multiproxy study of human/environment interaction in the Yalahau region, Quintana Roo, Mexico: Riverside, U.S.A, University of California, Riverside, $\mathrm{PhD}$ dissertation, 146 p.

Wollwage, L., Fedick, S.L., Sedov, S., SolleiroRebolledo, E., 2012, The deposition and chronology of Cenote T'isil: A multiproxy study of human/environment interaction in the northern Maya Lowlands of southeast Mexico: Geoarchaeology, 27(5), 441-456. 